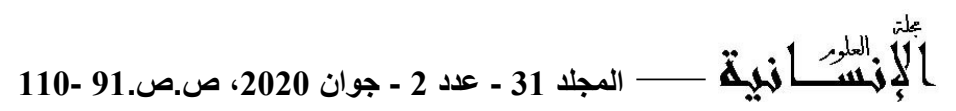

\title{
مسؤولية البنك عند رفض الوفاء بقيمة الثيك
}

The responsibility of the bank when refusing to meet the value of the

check

تاريخ الاستلام: 2019/07/04؛ تاريخ القبول: 2020/01/19

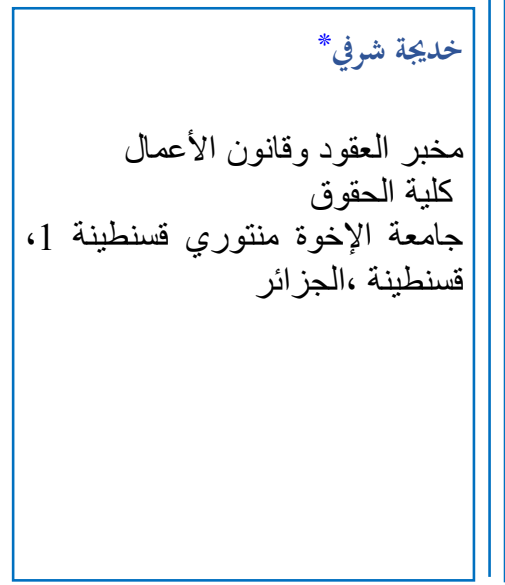

\section{Abstract}

The bank is obliged to cash the check to the bearer once it is submitted to him. When the correct value of the check is refused and when the value of the correct check available on sufficient balance is refused, it will be held responsible to the collector, a contractual liability and to the bearer of the latter a tort liability, on this unjustified refusal. However, legal exceptions allow the bank to refuse this undertaking despite the fact that it has received a valid check, when it is unable to act in return for the execution of an opposition or seizure of the balance, its absence or insufficiency, and therefore the refusal of the bank to pay the check is legitimate.

Keywords: Bank responsibility, illegitimate refusal to respect the value of a check, legitimate refusal to respect the value of a check.

\section{Résumé}

La banque est obligée d'encaisser le chèque à son porteur, une fois que celui-ci lui est soumis. Lorsque la valeur correcte du chèque est refusée, Et lorsque la valeur du chèque correct disponible sur solde suffisant est refusée il sera tenu responsable envers l'encaisseur, une responsabilité contractuelle et envers le porteur de ce dernier une responsabilité délictuelle, sur ce refus injustifié. Toutefois, des exceptions légales permettent à la banque de faire refuser cet engagement Malgré le fait qu'il ait reçu un chèque valide, lorsqu'il est incapable d'agir en contrepartie de l'exécution d'une opposition ou de la saisie du solde, son absence ou son insuffisance, et par conséquent le refus de la banque de payer le chèque est légitime.

Mots clés: responsabilité bancaire, refus illégitime de respecter la valeur d'un chèque, refus légitime de respecter la valeur d'un chèque.

* Corresponding author, e-mail: Cheurfi.khadidja@umc.edu.dz

$$
\text { (C) جامعة الاخوة منتوري قسنطينة 1، الجزائر } 2020 .
$$


تعتبر الثنيكات أداة وفاء بمجرد الاطلاع، حيث يجب إنب أن يكون مقابل الوفاء

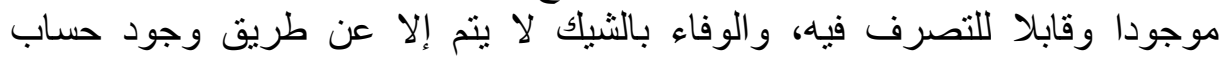

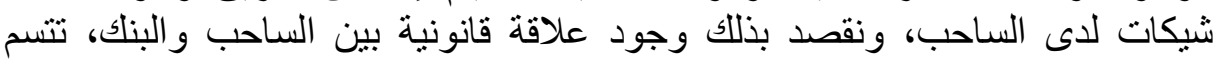
بوجود اتفاق صريح أو ضمني يخول صاحب الحساب إجراء مسحوبن بناته بموجب

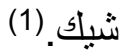

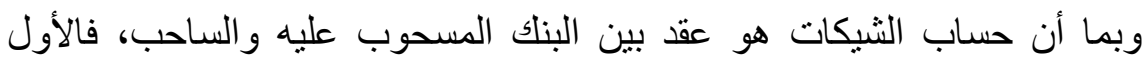

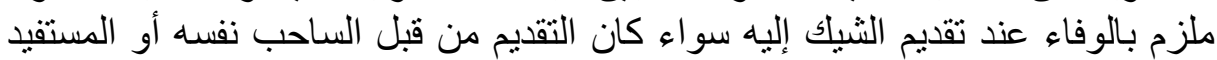

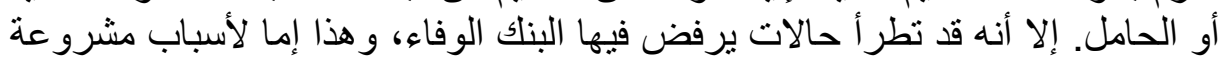

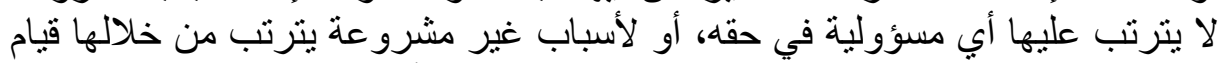

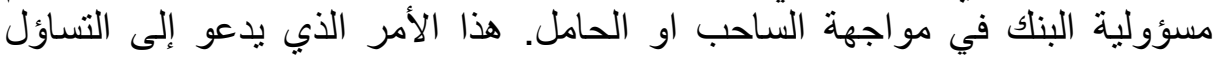

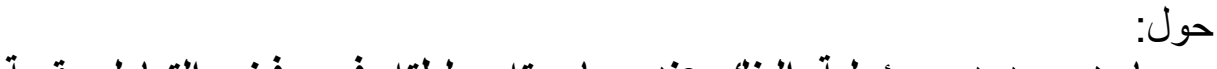
ما هي حدود مسؤولية البنك عند ممارسته سلطته في رفض التعامل بقيمة

للإجابة على هذه الإشكالية والإحاطة بمختلف جوانب الموضوع اتبعنا منهجا

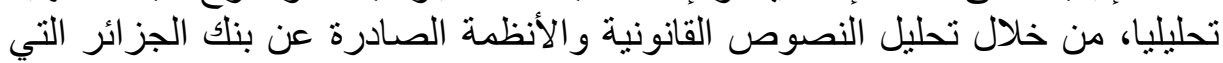

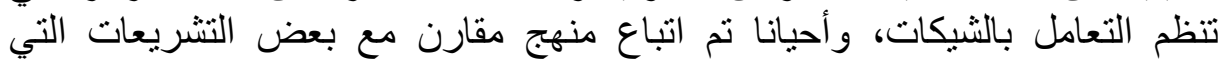
أثنارت إلى حالات رفض المسحوب عليه الوفاء الوفاء بالثيك.

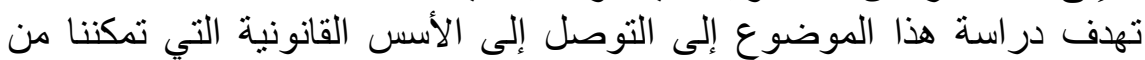

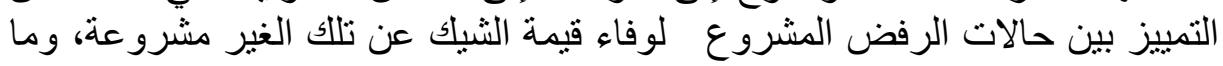

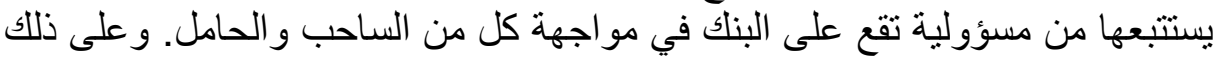

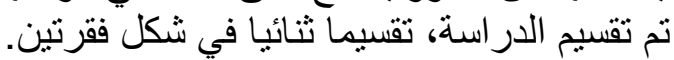

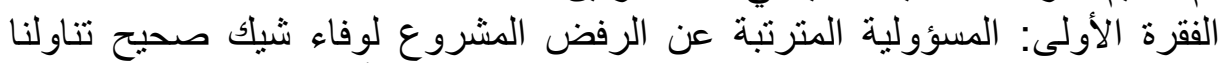

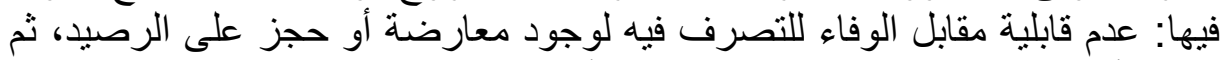

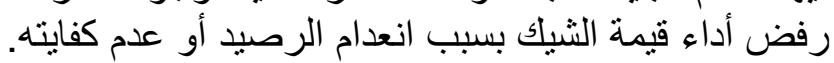

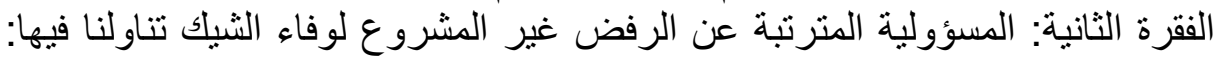

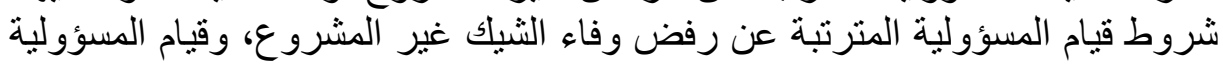

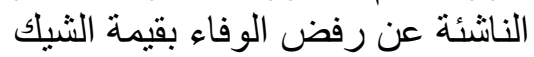

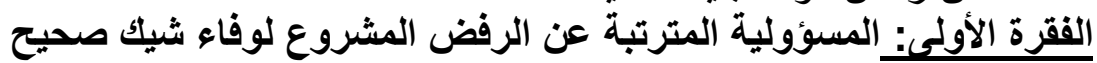

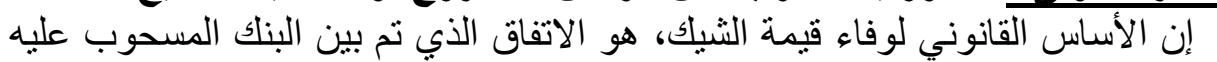

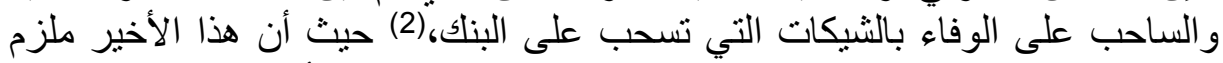

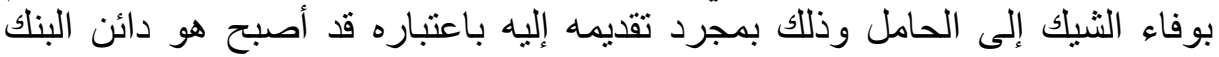

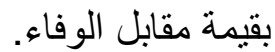
إلا أنه توجد استثناءات قانونية تمكن البنك من تسبيب رفض الوفاء الوفاء بقيمة الثيك،

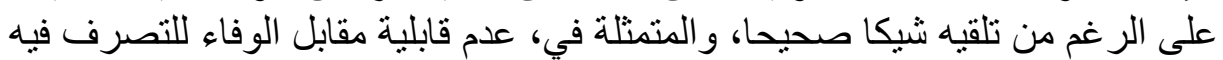

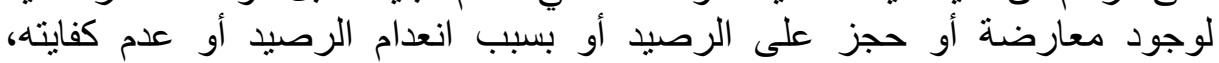

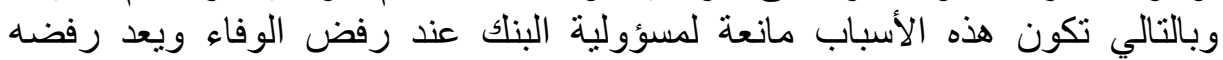
مشرو عالا.

أولا : عدم قابلية مقابل الوفاء للتصرف فيه لوجود معارضة أو حجز على الرصيد

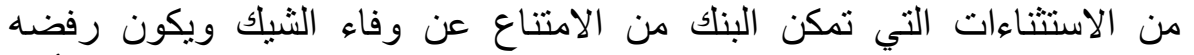

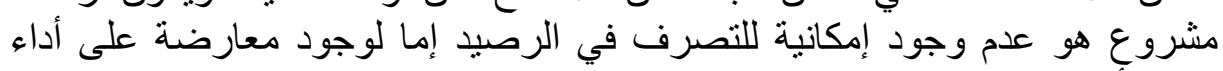
الثيك أو لحجز قد وقع على الروديد. 


\section{1-المعارضة على أداء الثيك}

من ضمن الحالات التي يحق للبنك رفض التهاء الوفاء بالثيك، دون أن يكون مخالفا

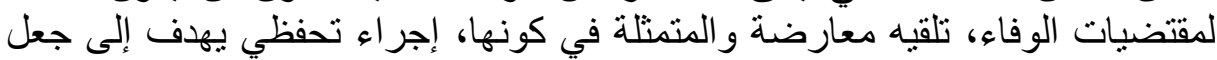

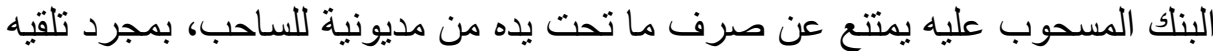

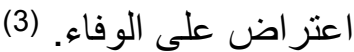

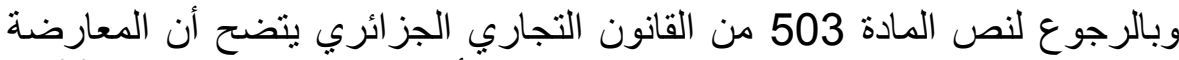

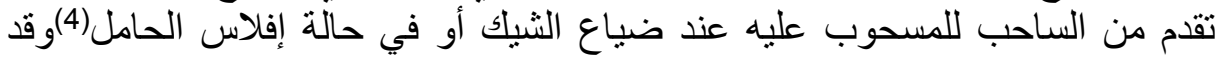

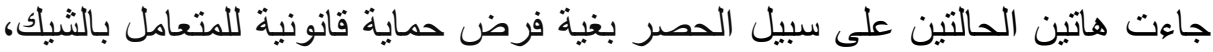

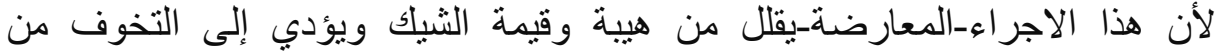

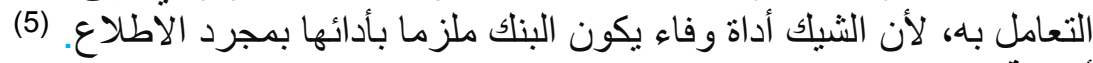
أ-حالة ضياع الثيك لأن الثيك

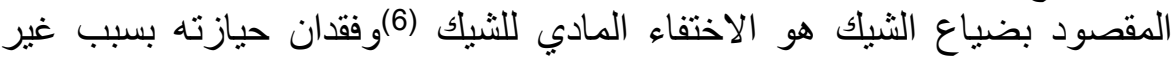

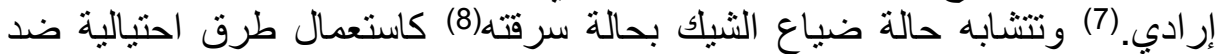

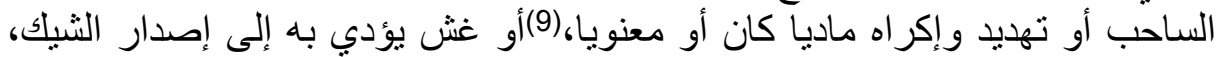

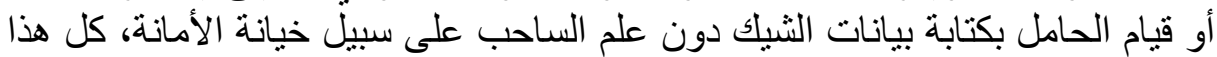

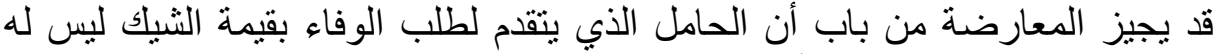

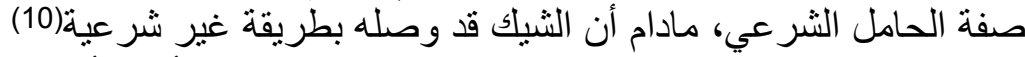

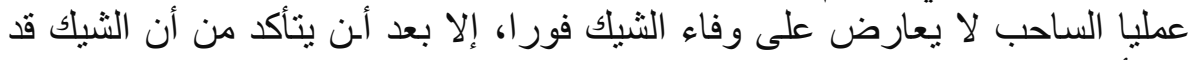

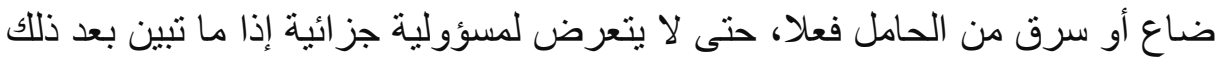

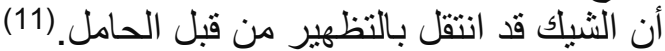

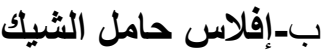

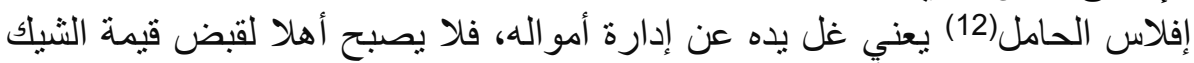

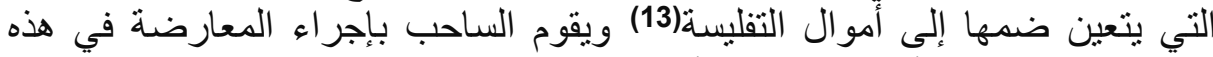

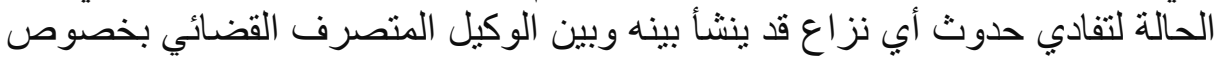

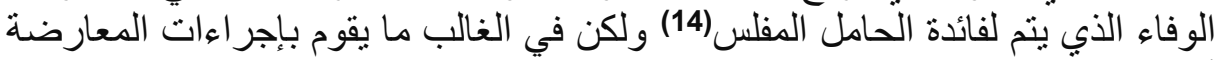

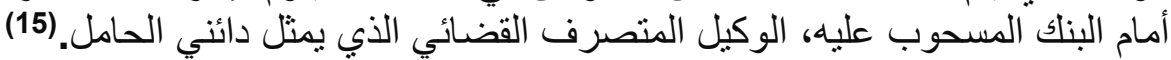

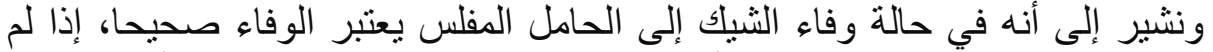

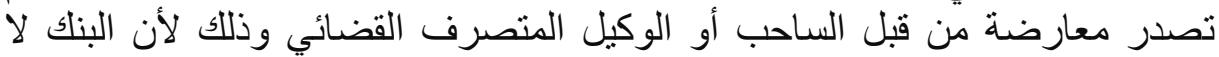

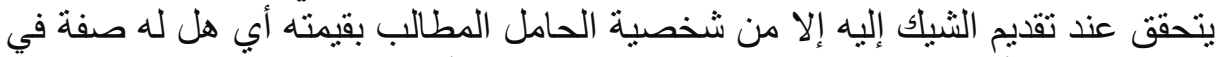

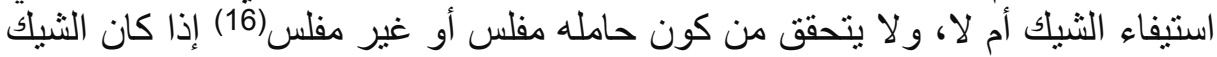

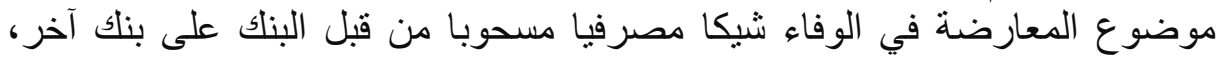

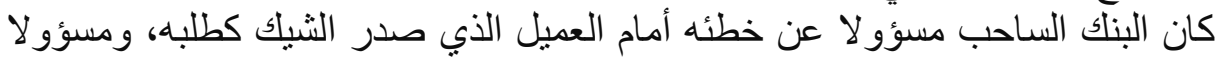

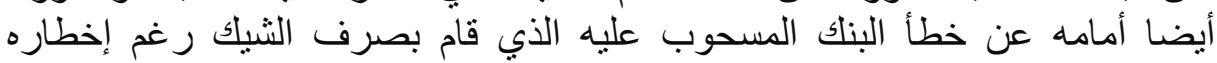

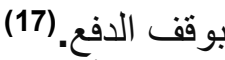

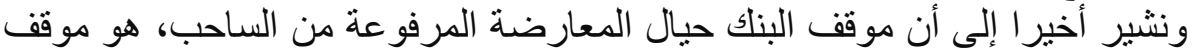

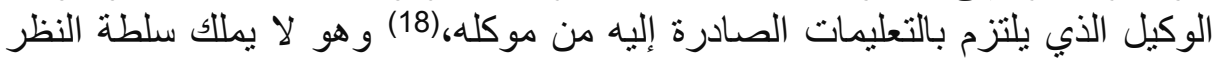

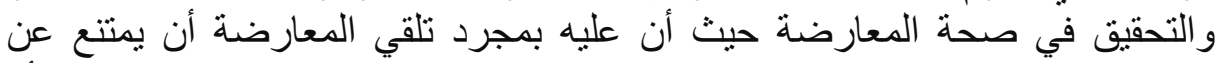

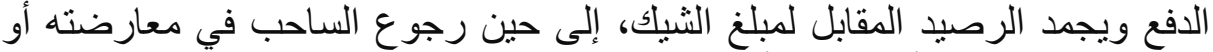

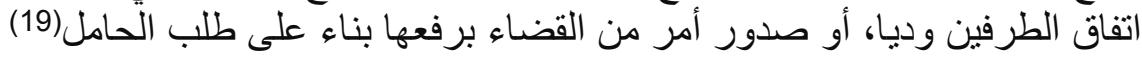

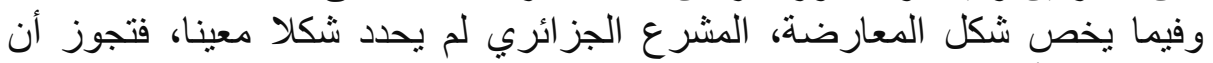

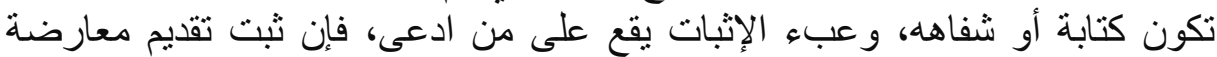
شفاهية وجب على البنك رفض الوفاء بقيمة الثيك.

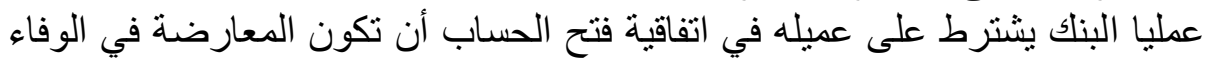

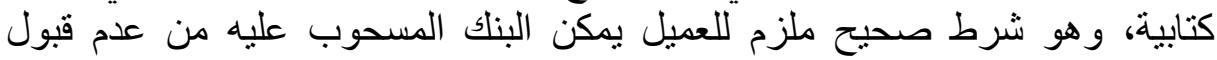
المعارضة الثفاهية. 


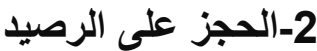

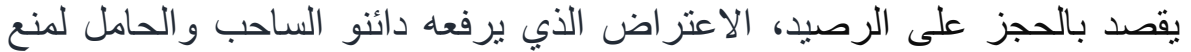

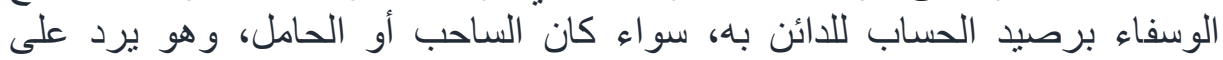

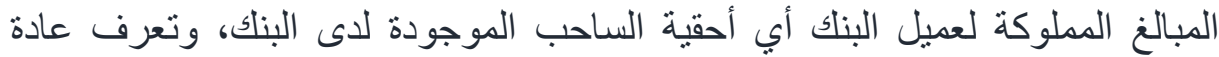

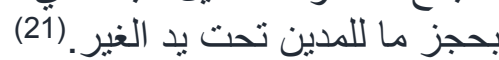

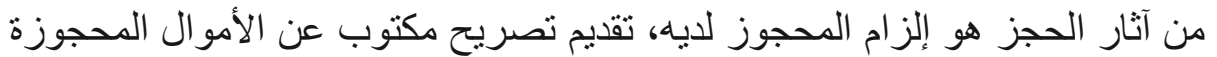

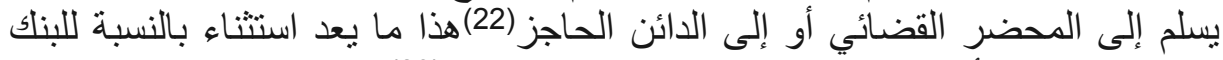

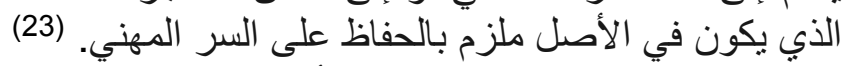

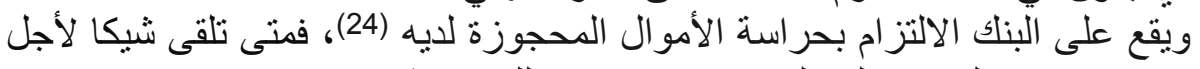

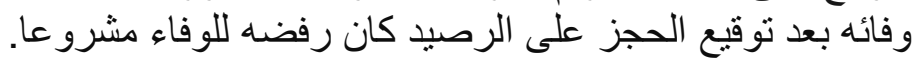

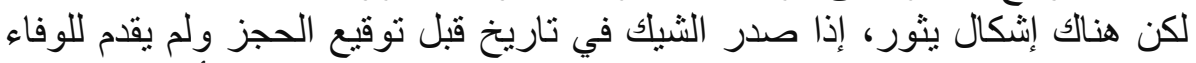

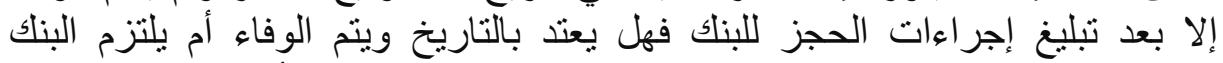

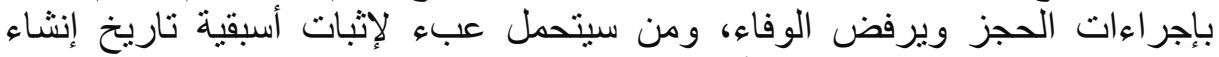

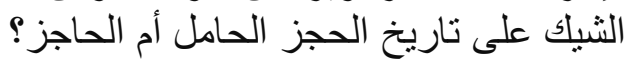

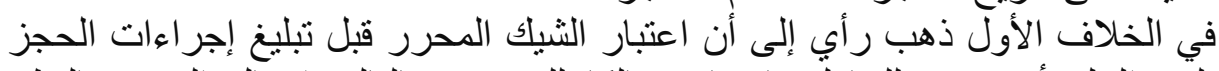

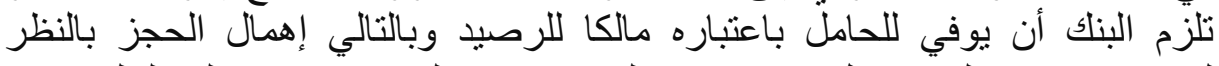

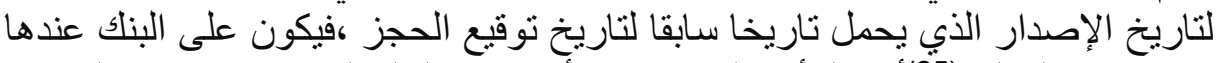

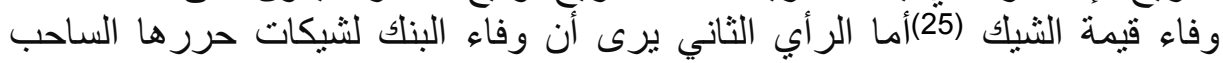

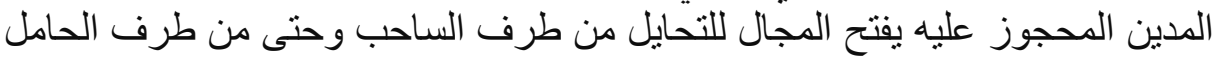

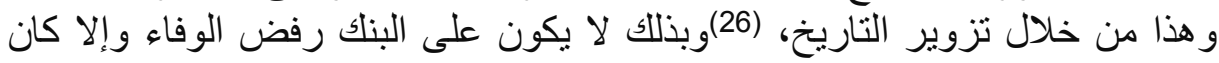

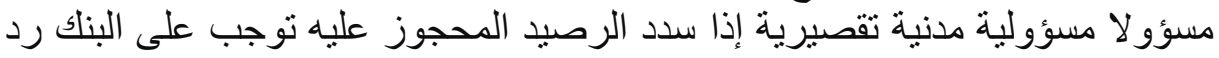

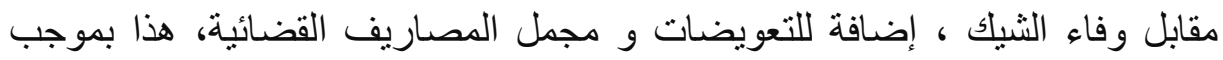

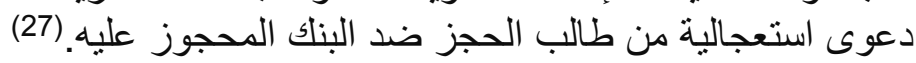

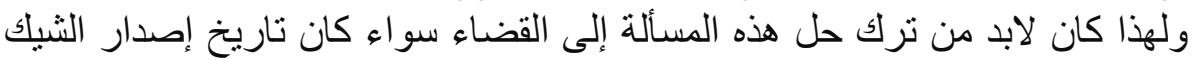

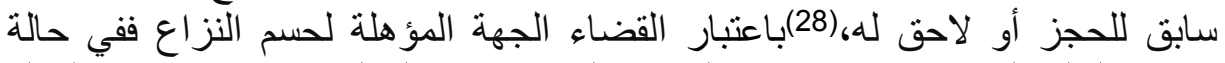

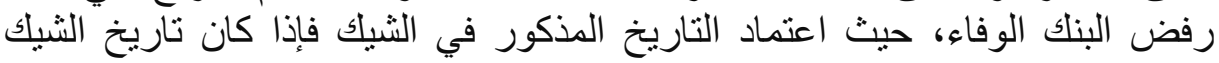

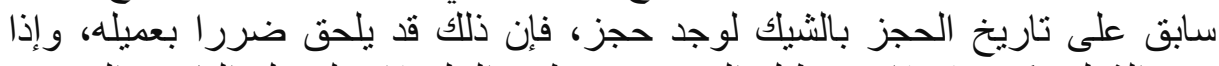

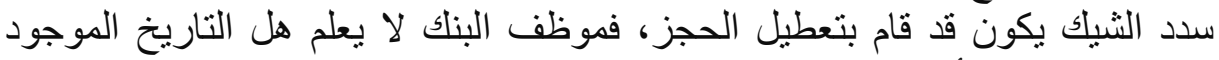
على الثيك سابق أو لاحق لإصد فئ لإصداره.

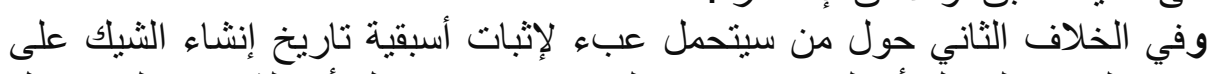

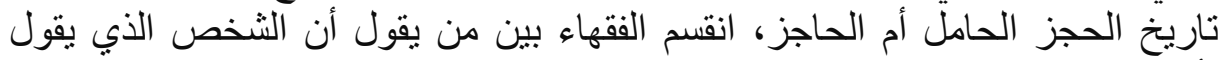

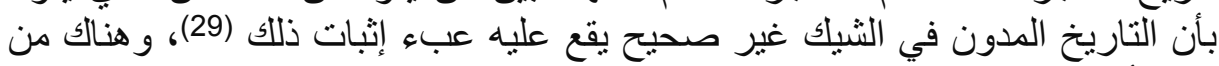

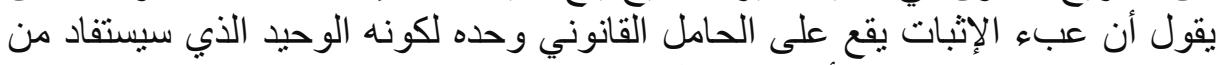

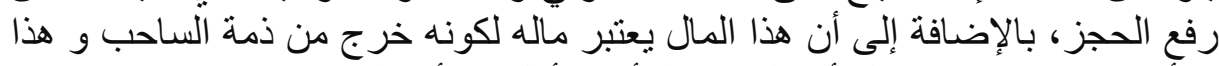

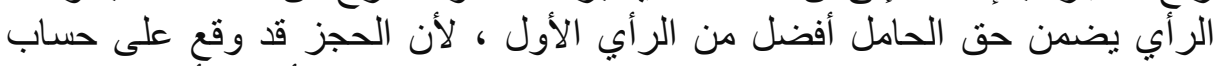

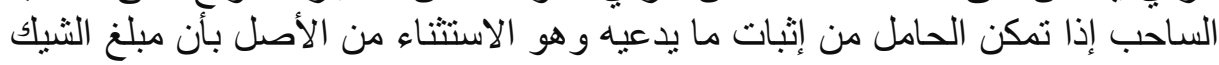

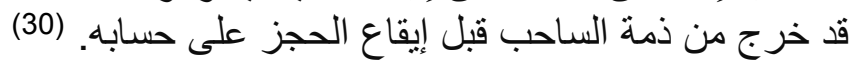

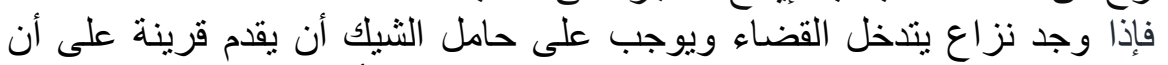

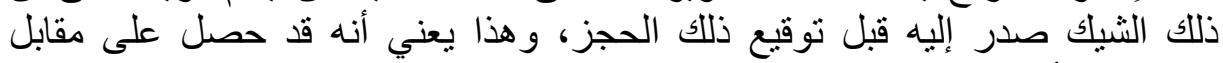

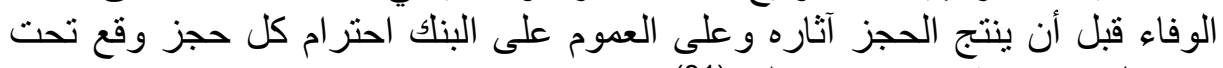

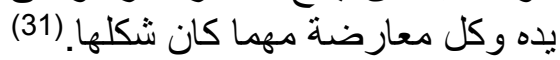
ومنه إذا وقع الحجز بشكل صحيح كان للبنك رفض رفان الوفاء بالثيك لكون الحجز الموقع

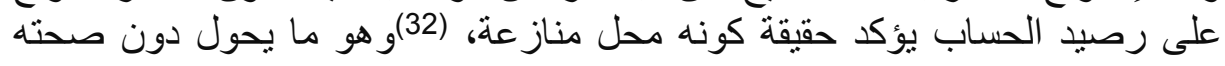


كمقابل وفاء للشيك.

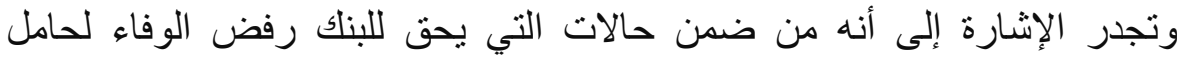

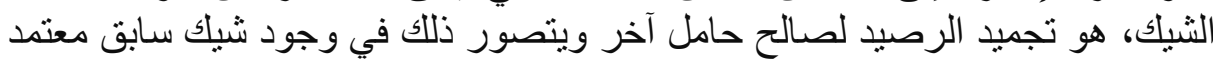

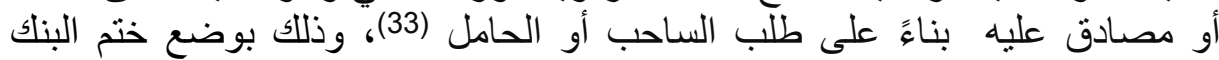

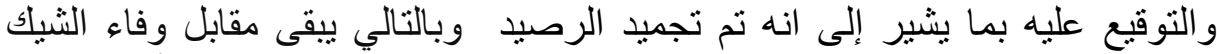

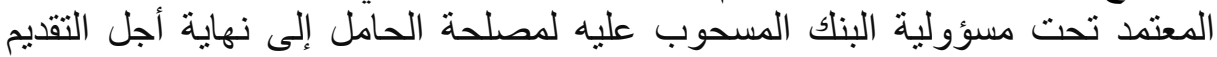

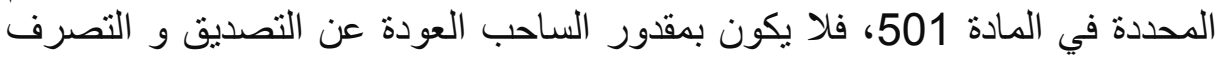

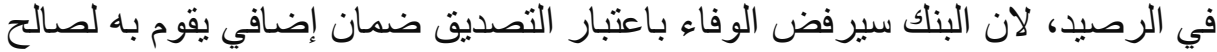

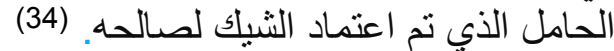

ثانيا: رفض أداء قيمة الثيك بسبب اعتباد النعام الرصيد أو عدام كفايته

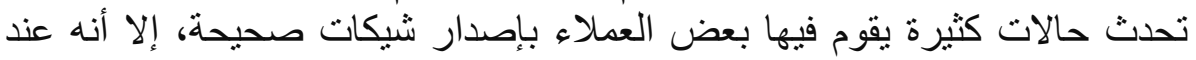

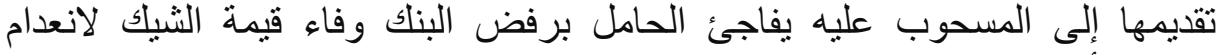

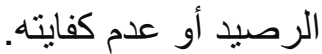
1-صور الرفض بسبب أرفي الرصيد يرفض البنك وفاء الثيك بسب رصبي رصيد منعدم تماما أو لعدم كفاية الرصيد لتسديد كامل

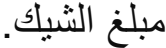

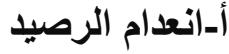
يعتبر الرصبد أهم الضمانات التي يعتمد عليها حامل الثيك في الحصول على قيمته، فقد اشترط مؤتمر جنيف أن يكون للثيك مبلغ يقابله لدى المئن المسحوب عليه بملكه الساحب ويستطيع التصرف فئن فيه (35)

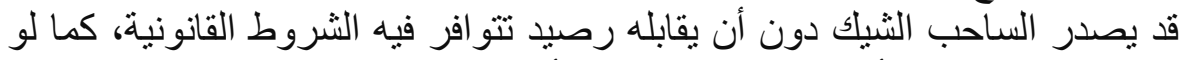

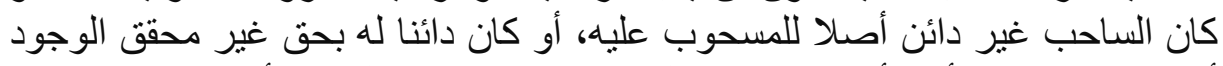

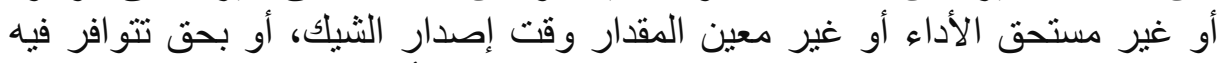
هذه الثروط ولكنه غير قابل للتصرف فيه بموجب شيك أو تقل قيمته عن مبلغ الثيك.

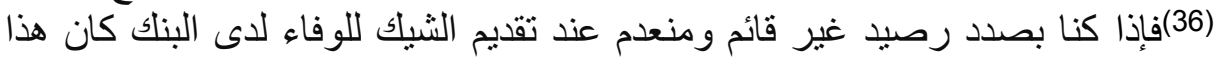

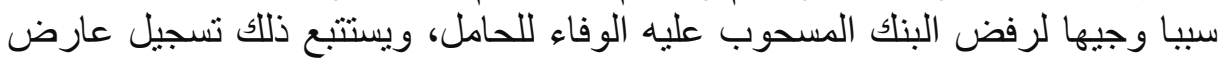

ب-عدم كفاية الرصيد

تعتبر حالة عدم كفاية الرصيد من الأسباب التي تستند عليها البنوك لتبرير الامتناع

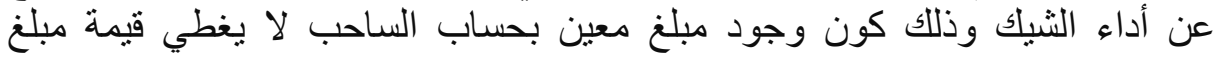

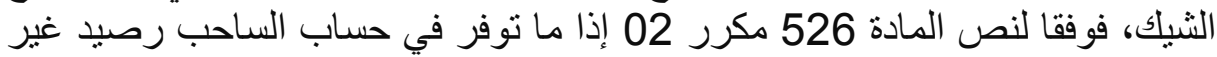

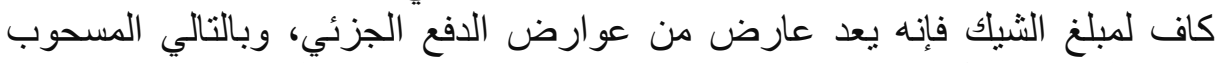

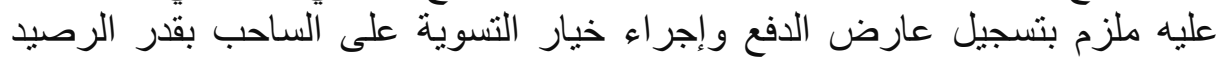
الناقص من قيمة الثيك.

2-التزام البنأك عند رفض الوفن الوفاء بسبب انعدام الرصيد أو عدم كفايته

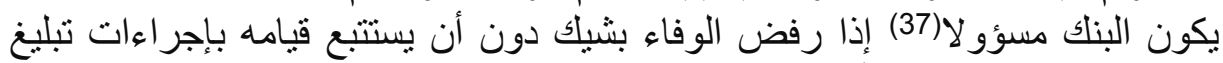

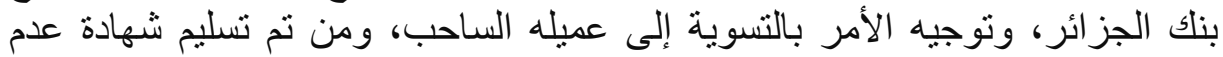

أ-إبلاغ مركزية المستحقات الغير مدفوعة:

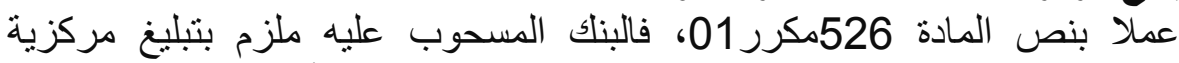

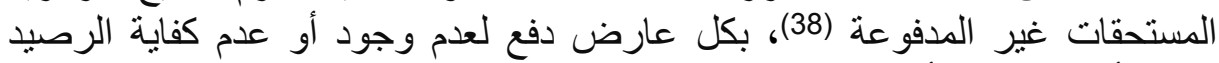

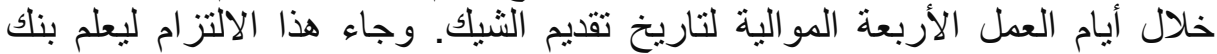

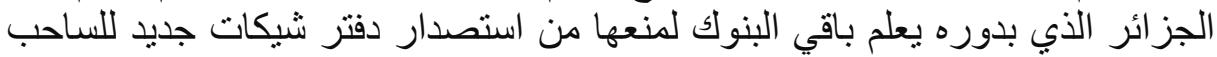

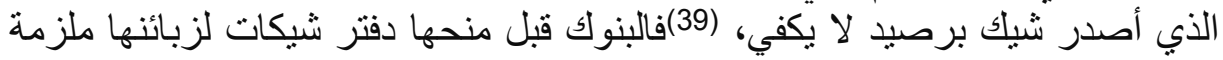

بالاطلاع على فهرس مركزية المستحقات غير المدفوعة لبنك الجز ائر ـ (40) 
بعد قيام البنك بإبلاغ مركزية المستحقات غير المدفوعة بوجود عارض دفع، قد يقوم

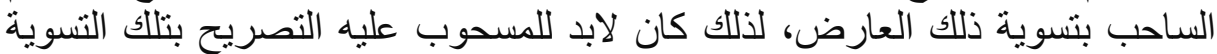

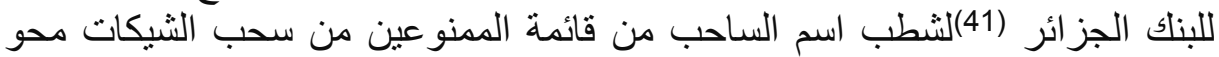

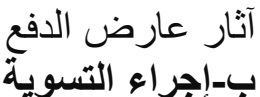

يجب على البنك المسحوب عليه بمناسبة أول عارض أله دفع لعدم وجود أو عدم كفاية

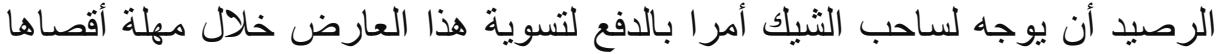

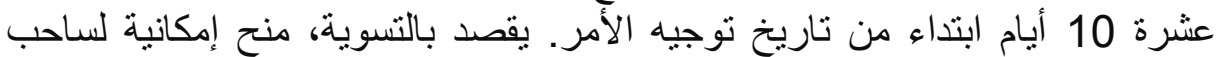

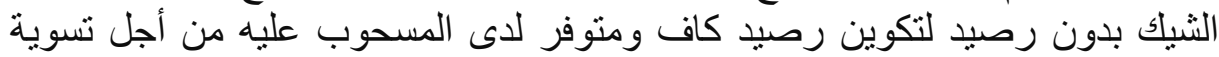

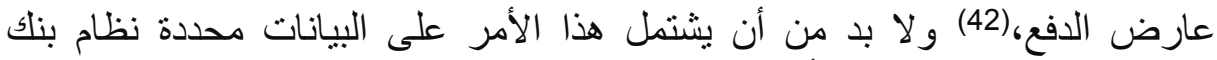

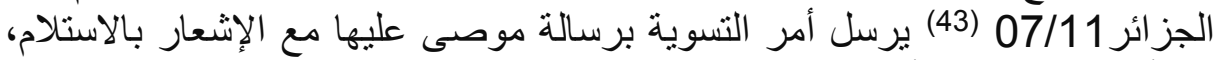

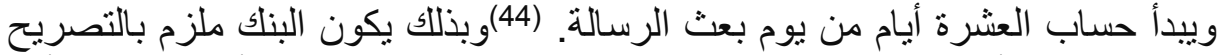

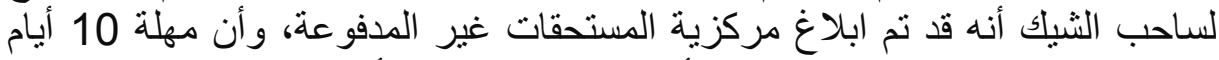

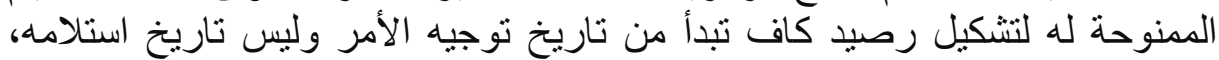
وفي هذا مساس لحق الساحب إذا ما استلم الرسالة بعد الأجل المحددة لتكوينه رصيد رصيد كاف.

إذا امتتع الساحب عن القيام بتسوية وضعيته خلال الآجال القانونية، وإذا ما قام إمار

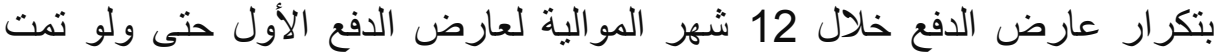

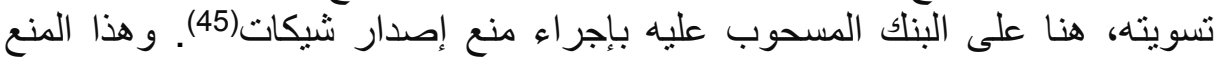

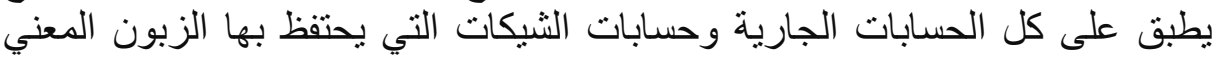

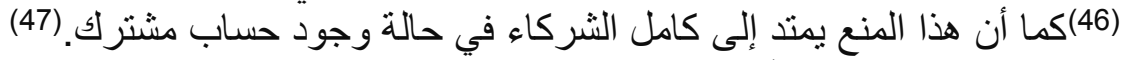

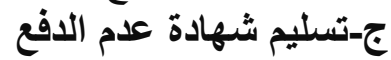
بمجرد تلقي البنك المسحوب عليه شيك ليس له رصيد كاف أو أو منعدم، يقوم بإعداد

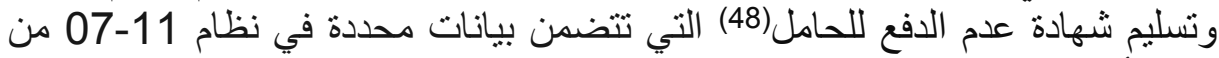

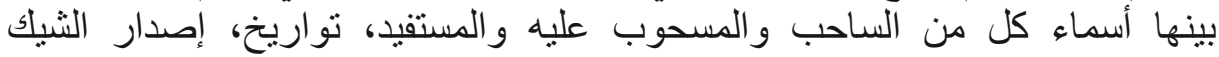

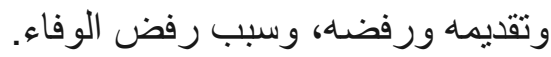

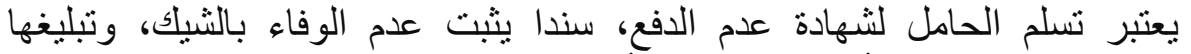

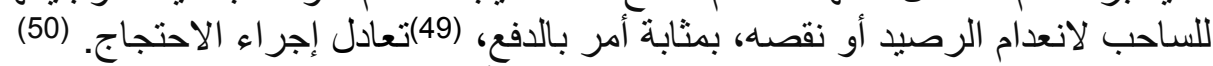

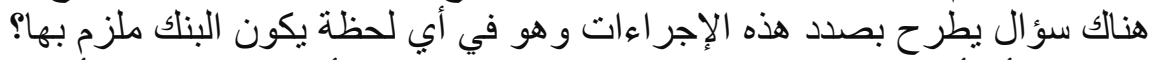

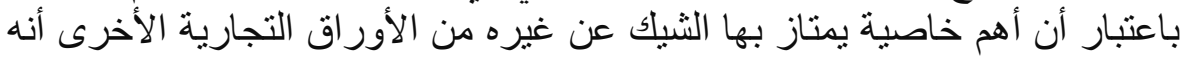

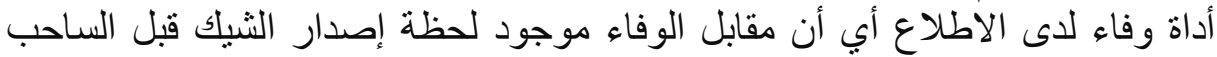

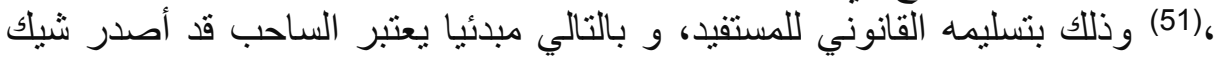

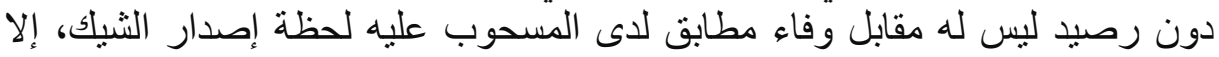

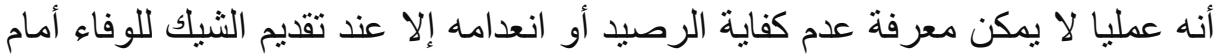

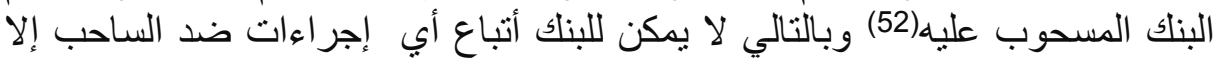

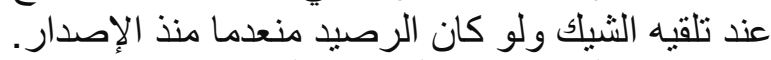

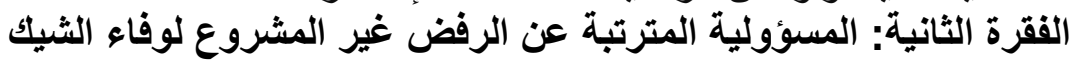

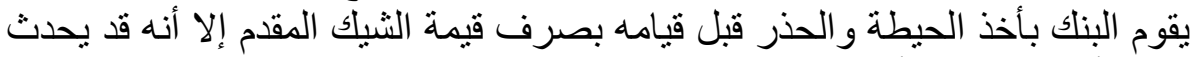

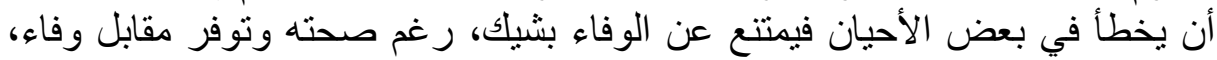

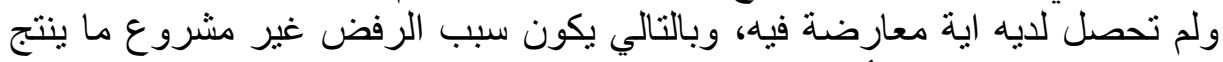

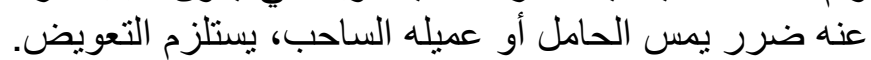

\section{أولا: شروط قيام المسؤولية المترتبة عن رفض وفاء الثيك غير المشروع}


لقد اشترط المشرع الجزائري قبل قيام مسؤولية البنك عن رفض الوفاء بقيمة الثيك

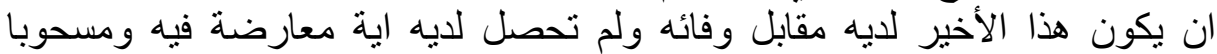

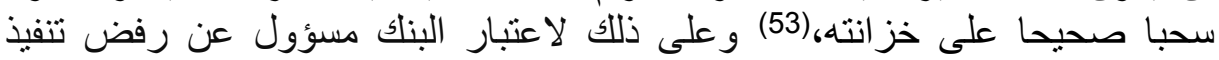

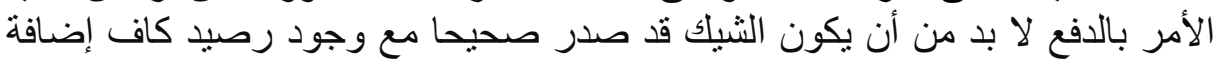

بعتبر الثيك صك مكتوب وفقا لأوضاع شكلية حددها القانون (54) بموجبه يأمر

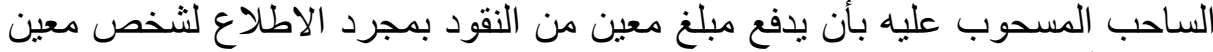

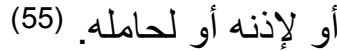

ونشير إلى أن مختلف التشريعات قد نظمت تحديد بيانات الثيك تحت عنوان * إنشاء

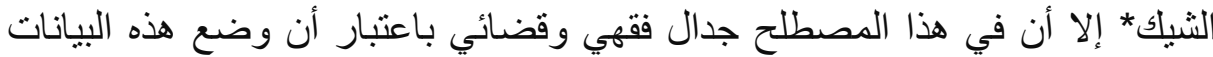

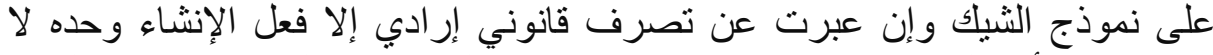

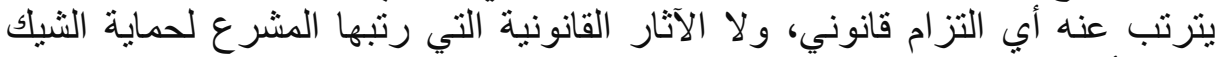

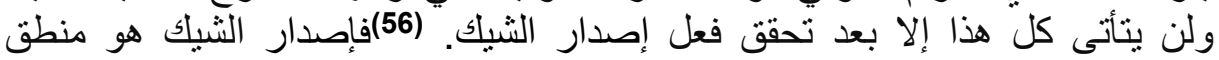

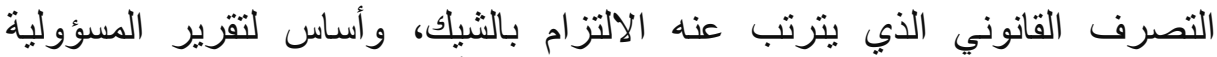
والحماية القانونية لحامله، وتقرير هذه المسؤولية أيضا يتوقف على على مدى اعتى التبار

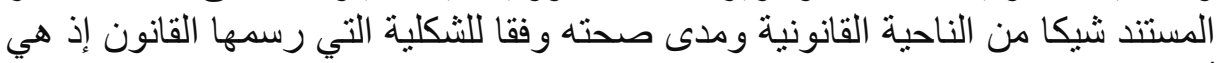

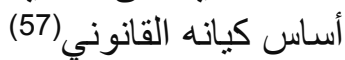
ويطر ح موضوع صحة تأسيس الثيك إذا ما توفر هذا الأخير على مجمل بياناته التي التي

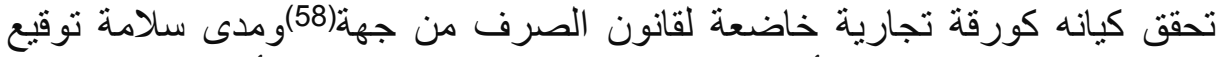

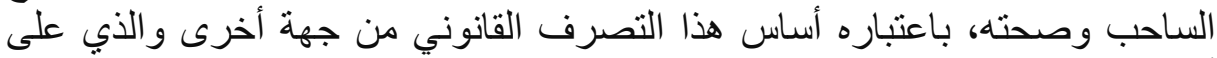

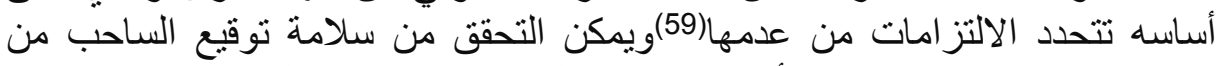

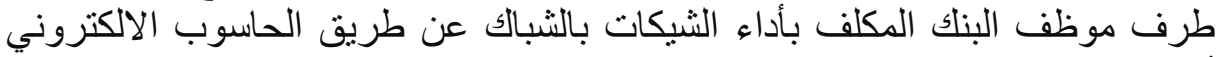

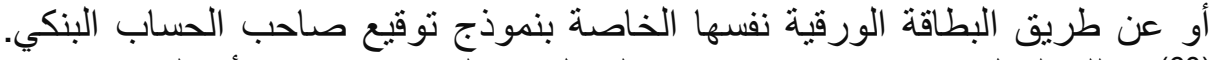

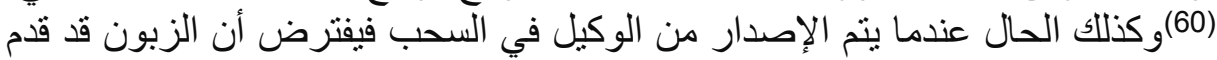

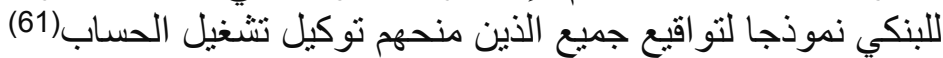

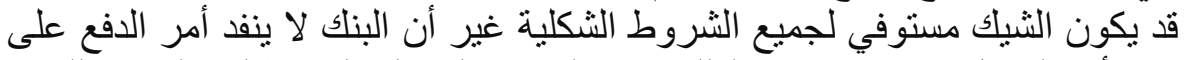

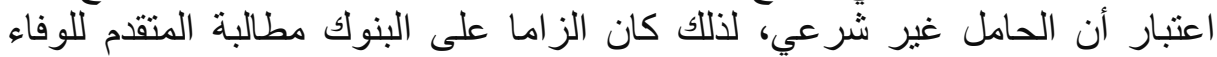

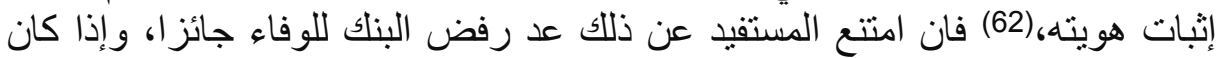

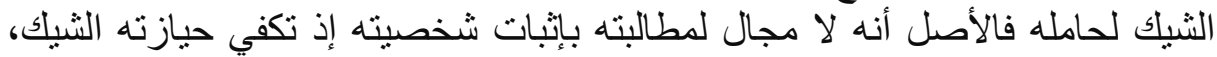

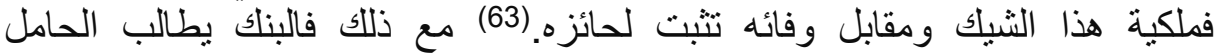

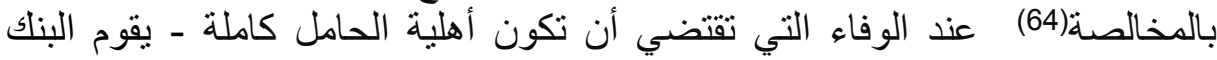

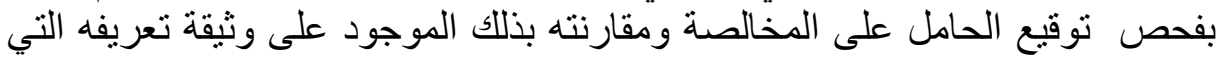

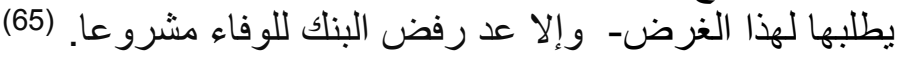
2-وجود مقابل الوفاء يفترض مقابل الوفاء وجود مقابل الوفاء علاقة قانونية بين الساحب، و البنك و المسحوب عليه

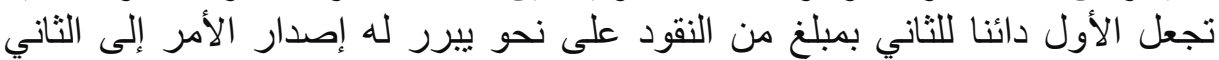

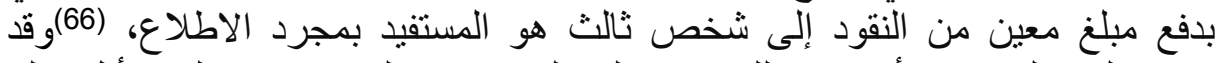

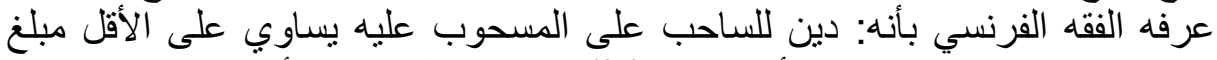

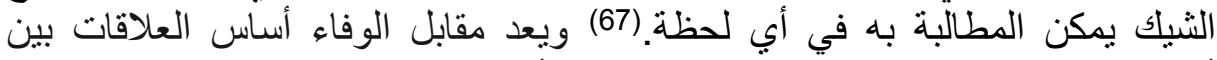

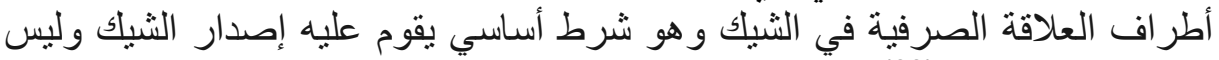

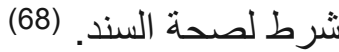
ولذلك قبل قيام مسؤولية البنك عن رفض الوفة الوفاء بقيمة الثيك وجب ونب أن يستوفي مقابل

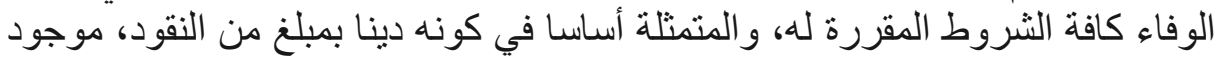
وقت إنشاء الثيك(69) هناك إمكانية للتصرف فيه،(70) فاذا نوفرت هذه الثناء دن الثروط فلا 


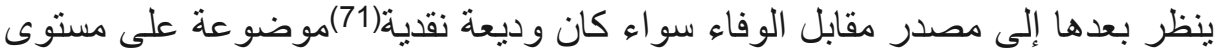

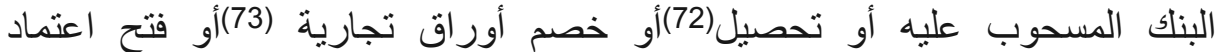
(74)المصلحة العميل الساحب يتم الاتفاق على التصرف فيه عن طريق إصدار شيكات

إن فرضية وجود مقابل الوفاء كاملا ليست الوحيدة التي توجب قيام مسؤولية البنك بل

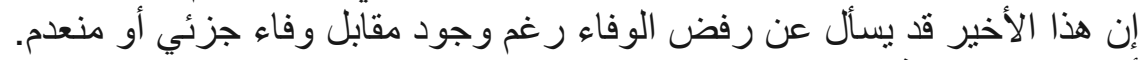
أ-وجود مقابل وفاء جزئي

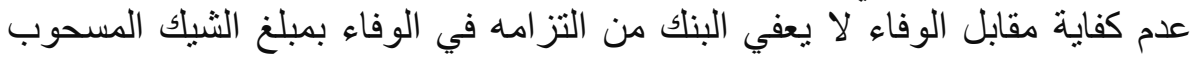

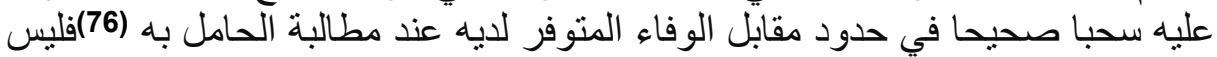

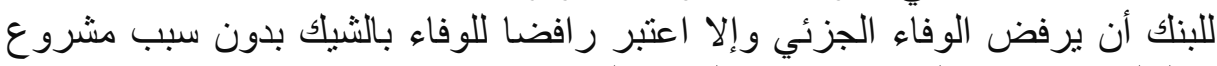

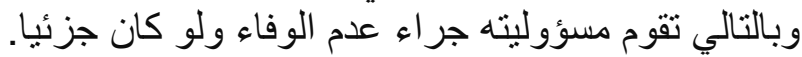
و السؤال الذي يثار بهذا الصدد هل تقوم مسؤولية البنك في رفض الوف الوفاء الوفاء الجزئي إذا لم

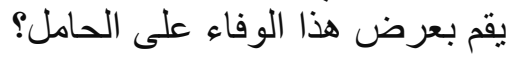

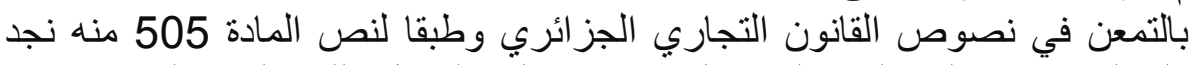

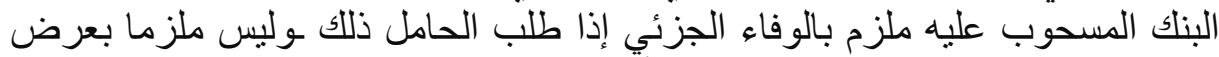

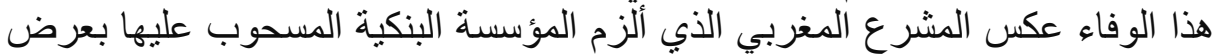

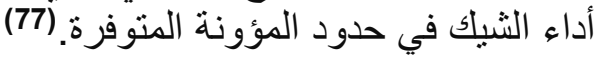

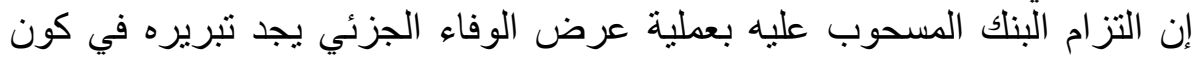

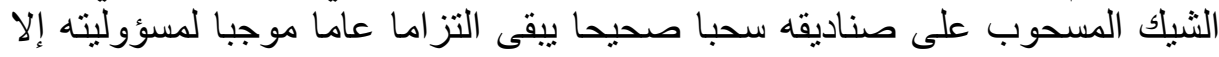

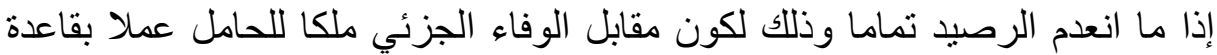

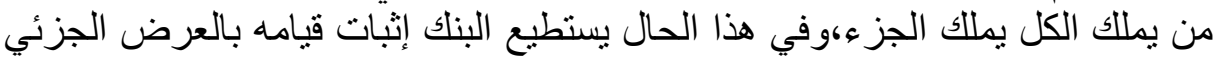

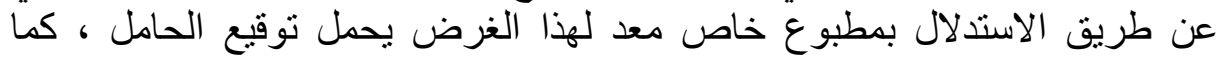

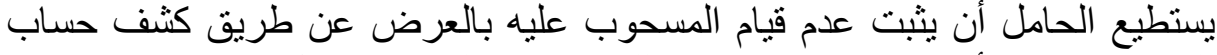

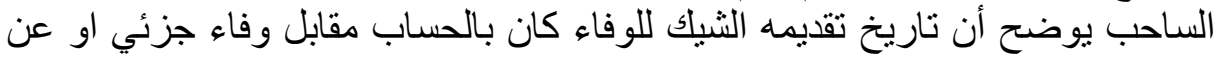

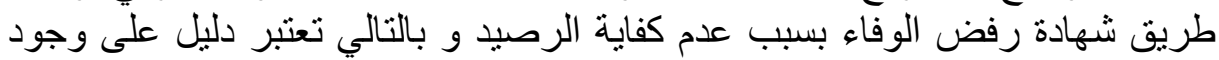

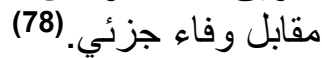

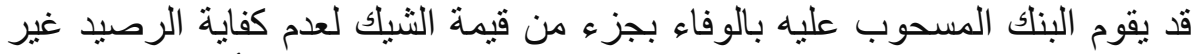

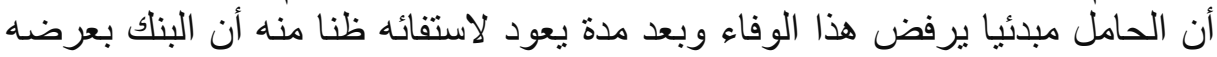

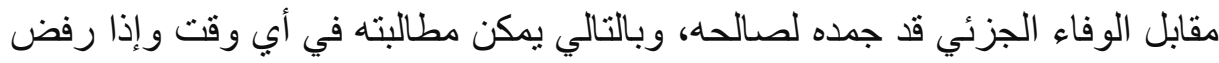

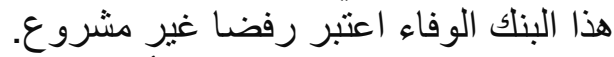

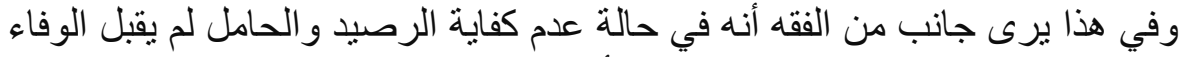

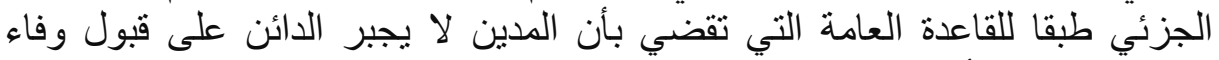

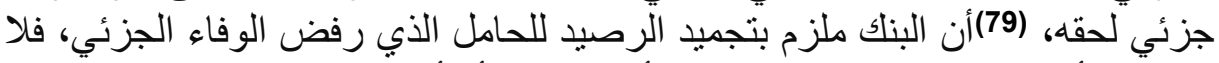
يجوز لله أن يوفيه إلى الساحب حتى يستأذن الحامل أو أن يسترد الساحب حكما قضائيا

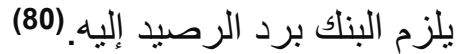

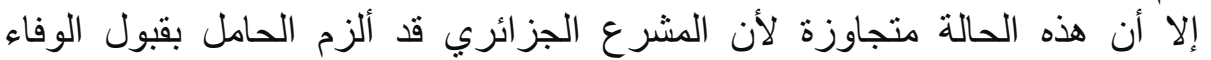

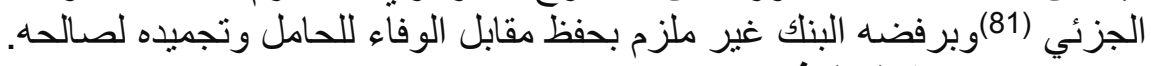

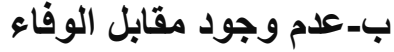

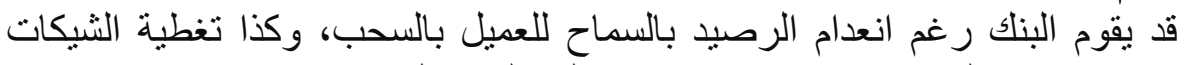

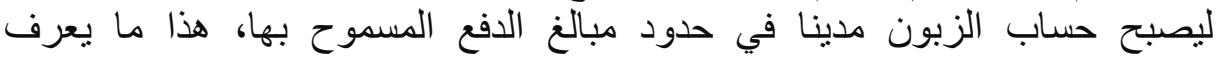

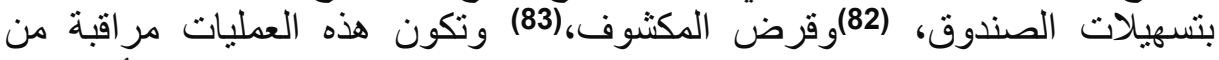

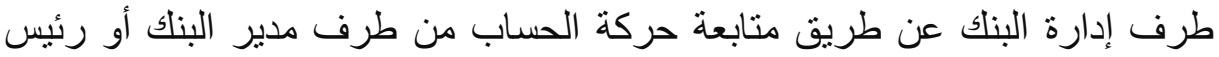

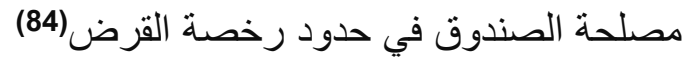




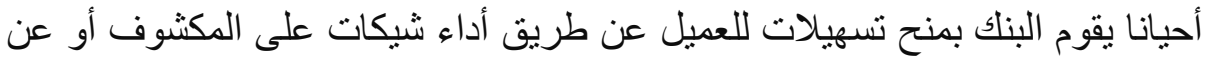

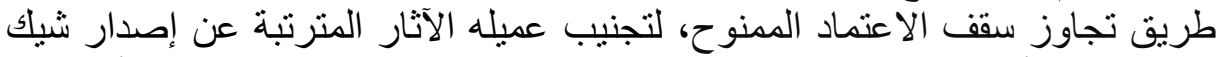

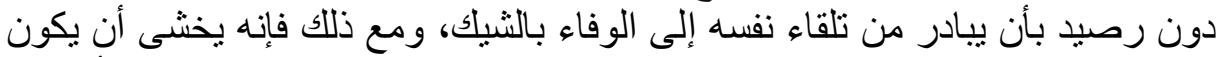
هذا الوفاء سبيا لقيام مسؤوليته لو رفض لإن لاحقا وبشكل مفاجئ الوفاء بشيك أصناء أصدره

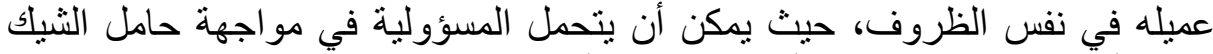

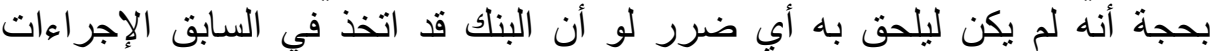

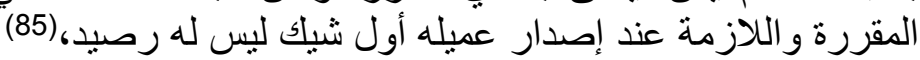

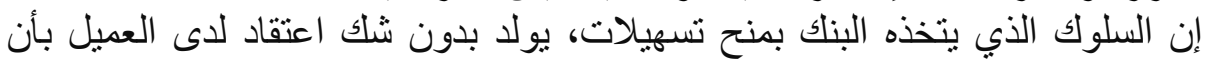
البنك سوف يدفع الثيكات الصادرة منه بالر غم من عدم وجود الرصيد الت أو كفايته، وقد

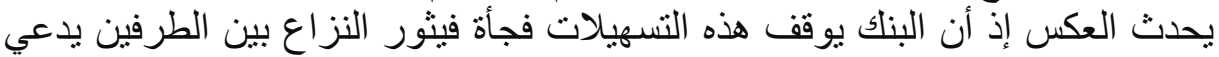

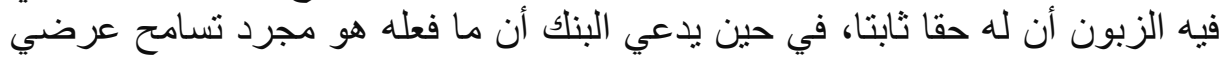

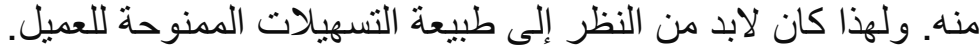

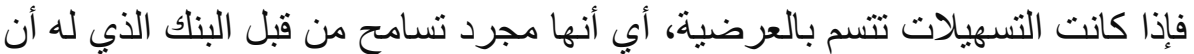

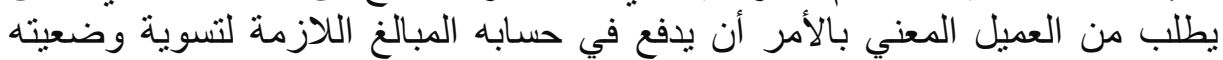

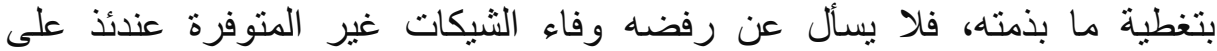
الرصبد، حتى ولو كان قد سبق له أن أفاد العميل من هذه الخدمة فئه في الماضي.

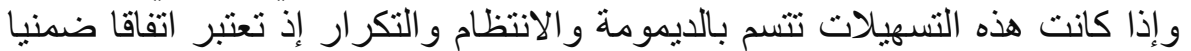

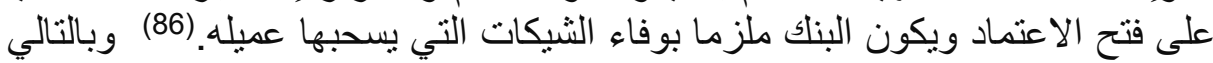

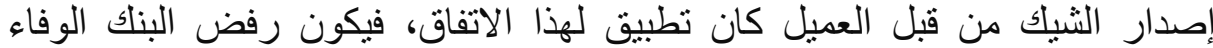

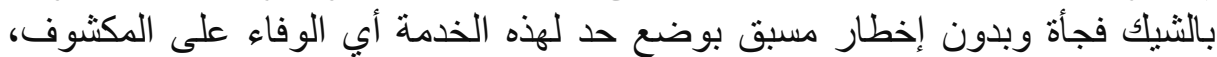

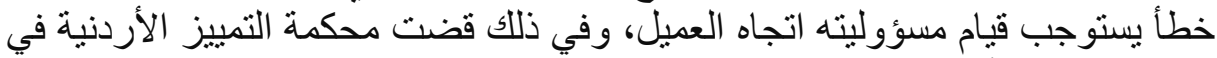

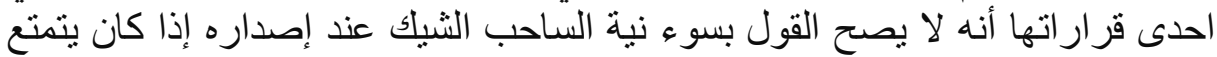

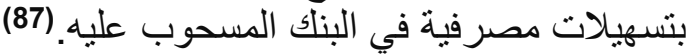
ونشير أخيرا إلى أنه قد يكون للساحب مبالغ متمثلة في ودائع لأجل، أو شهادات

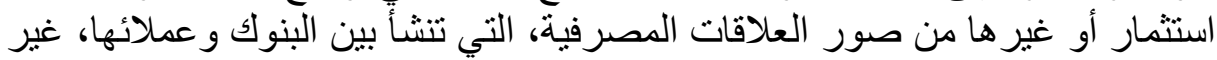

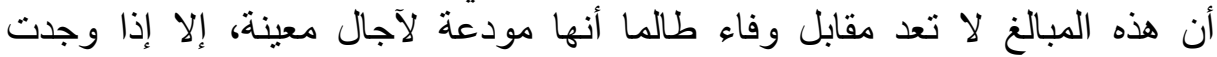

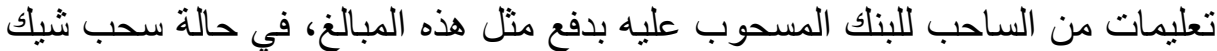
لا يتو افر على رصبد سواء كانت هذه التعليمات صريحة أم ضمنئية.

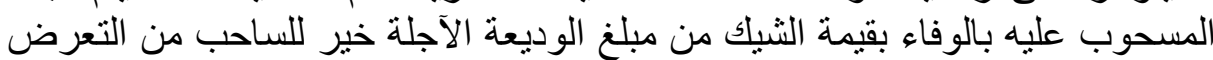

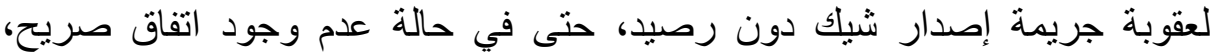
يفترض بالبنك أن يتدخل ضمنيا لأجل الوفاء بالثنيك حرصا على سمعة العميل

و مصلحته. (89)

ثانيا: قيام المسؤولية الناشئة عن رفض الوف الوفاء بقيمة الشيك

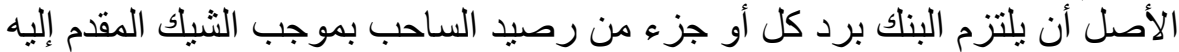

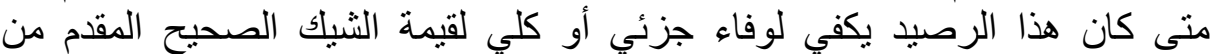

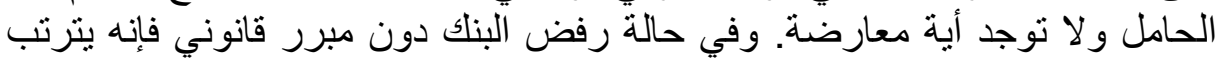

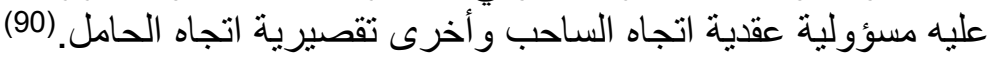
1-مسؤولية البنك العقدية

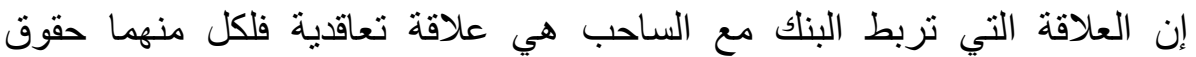

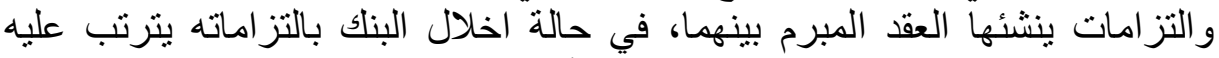

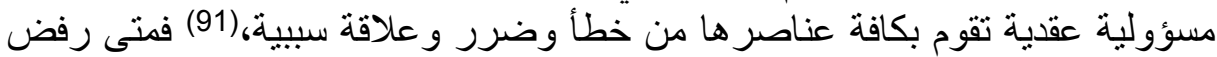
البنك المسحوب عليه الوفاء بقيمة الثيك المتوفر على رصيد كاف وبدون معارضة يعتبر مسؤولا عن رفض الو الوفاء في الوفي مواء اجهة الساحب.

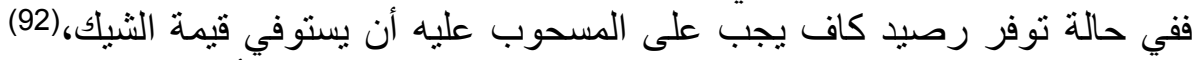

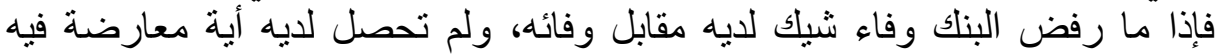


ومسحوبا سحبا صحيحا على خزانته، يكون مسؤو لا اتجاه الساحب بتعويض الضرر الناشئ له عن عدم تنفيذ أمره و وعما لحقه في سمعته. (93)

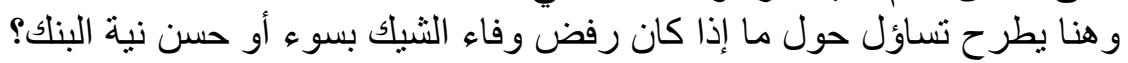

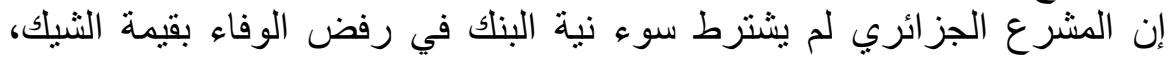
فيستوي في ذللك أن يكون الرفض بسو أرو أو بحسن نية، كأن يخطأ البنك في حساب قدر الرّاء

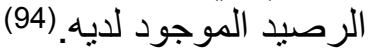

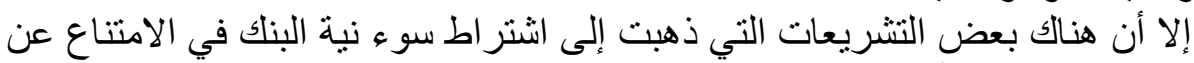

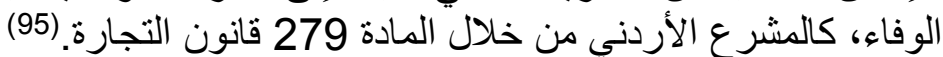

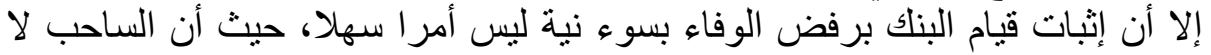

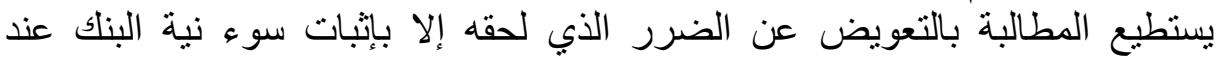

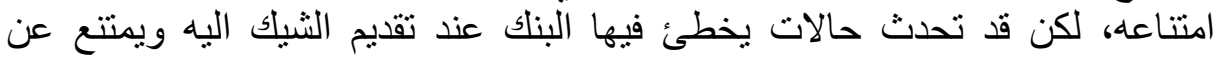

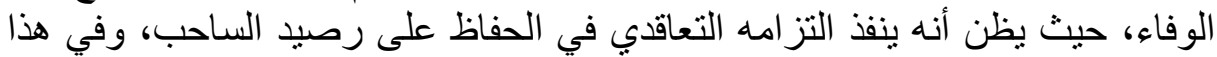

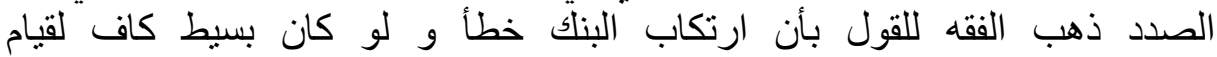

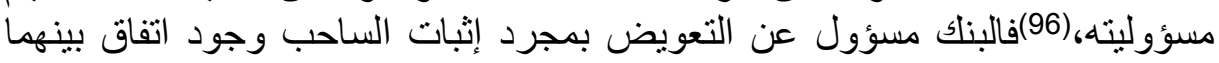

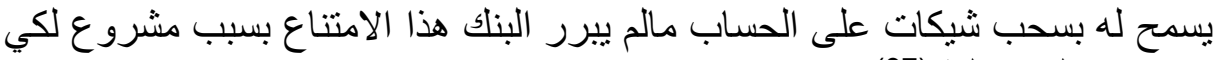
ينفي عنه المسؤولية. (97) ولَّهذا نجد المشر ع الجزائري تجنب اشتر اط سوء نية البنك في رفض الوفاء الوفاء، فبمجرد

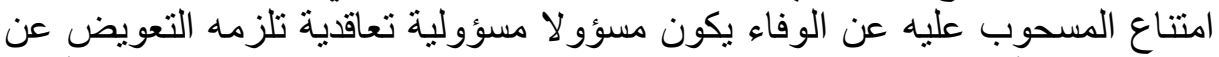

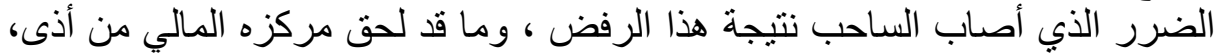

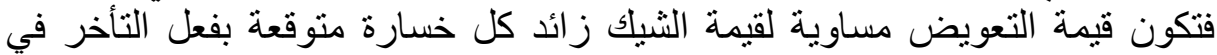

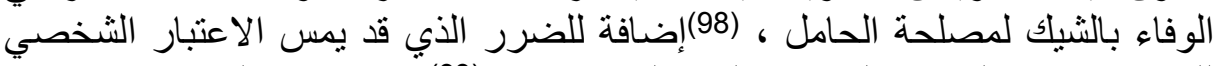

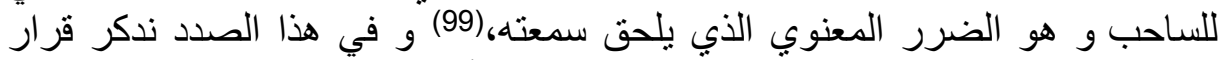

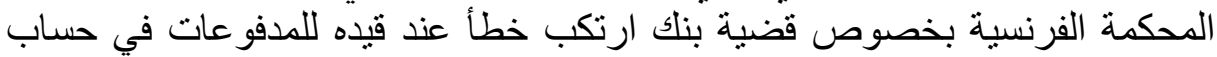

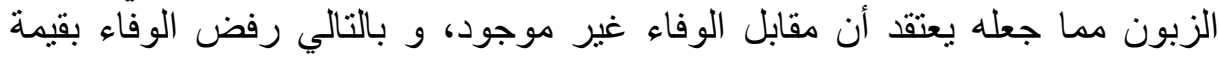

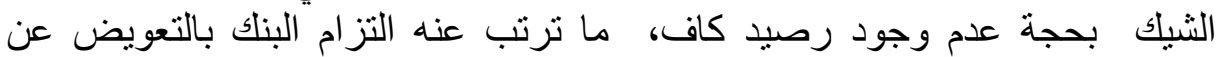

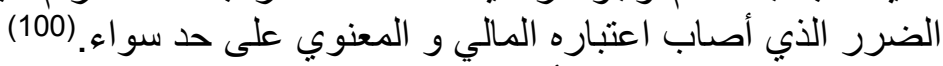

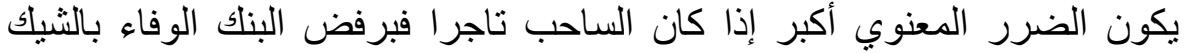

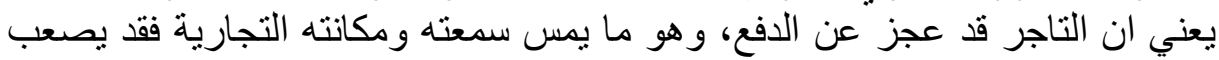

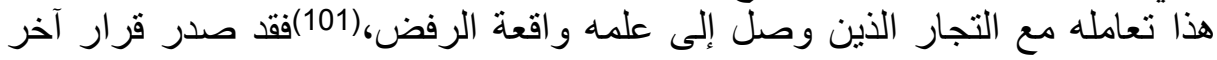

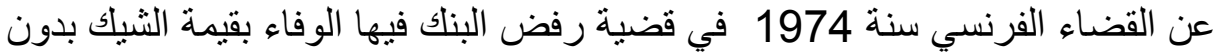

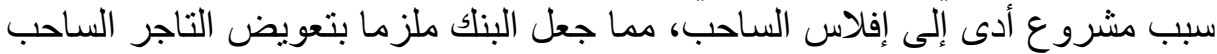
عن ديونه التي كانت عليه، إضافة إلى الضرر المعنوي الذي لحقه جراء الذياء إعلان إفلاسه. (102)

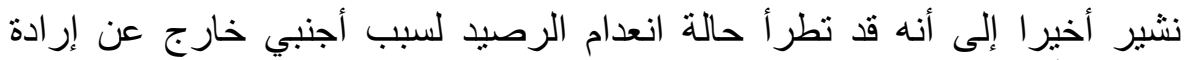

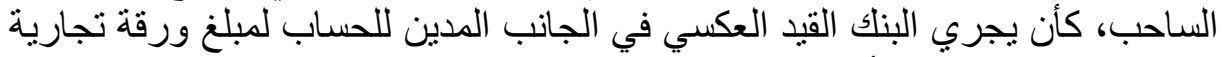

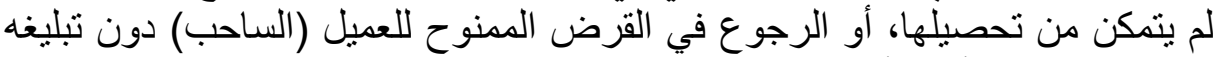

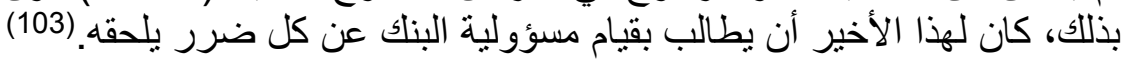
2-مسؤولية البنك التقصيرية

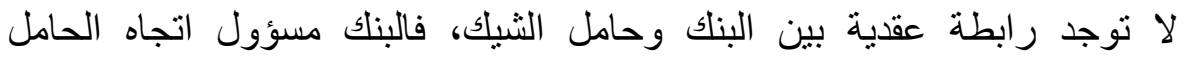

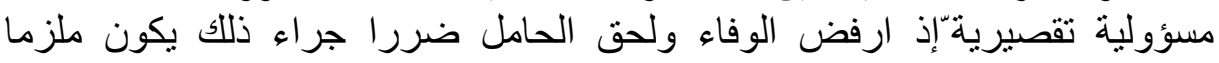

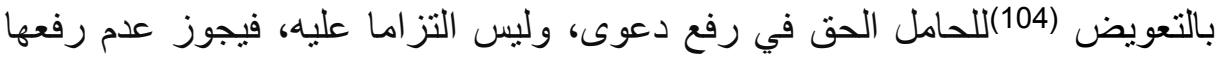
و الرجوع على الساحب وغيره من الموقعين على الثيك بمجرد رفض رفض البنك الوفاء 


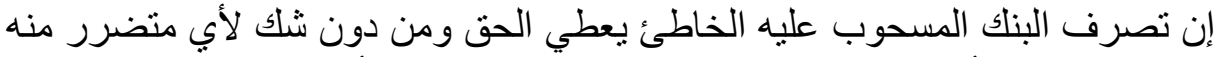

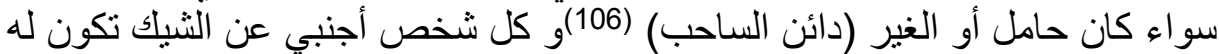

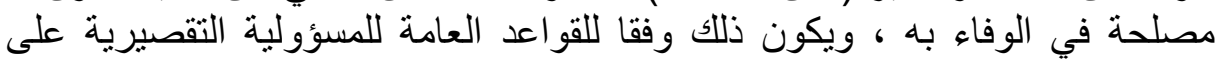

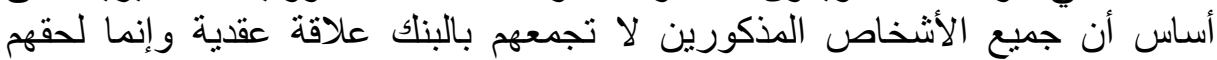

ضرر بسبب خطأه. (107) - (10) يكون البنك المسحوب عليه مسؤولا عن عدم تسديده شيك لارتكابه خطأ في حالات

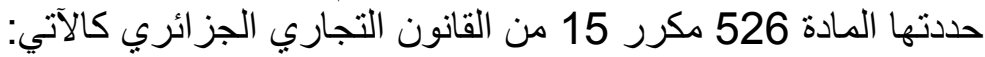

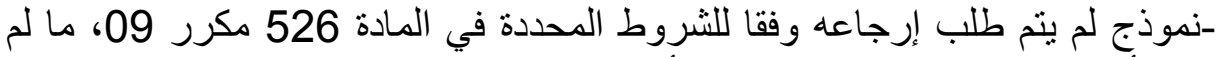

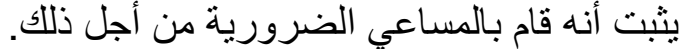

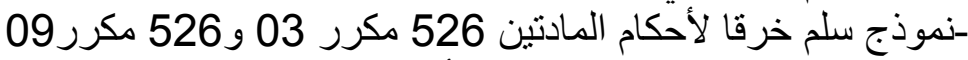

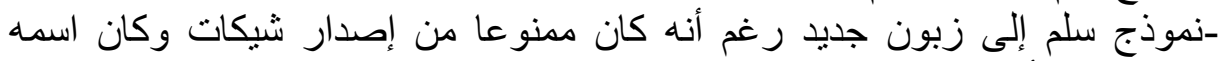

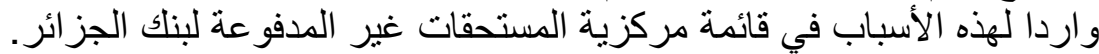

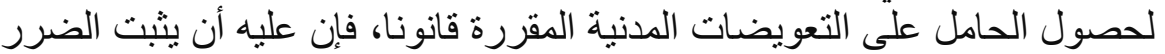

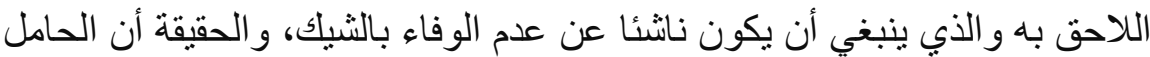

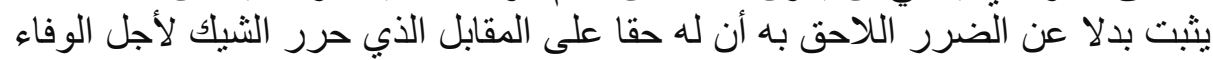

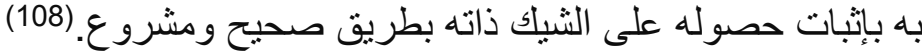

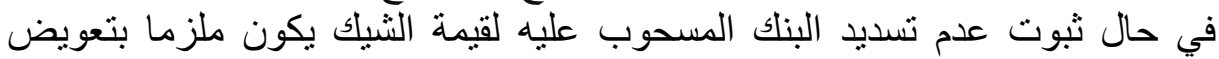

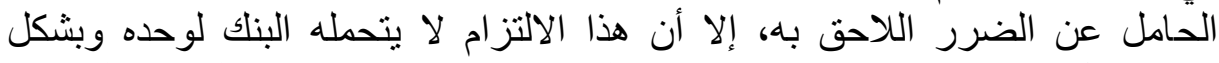

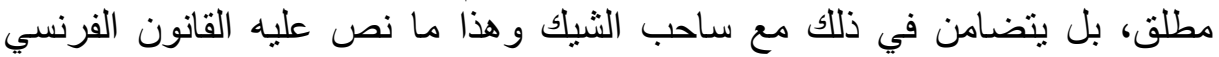

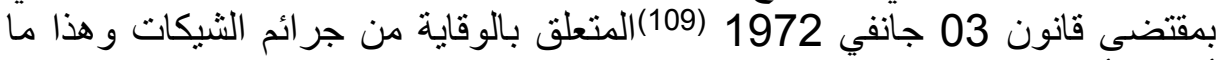

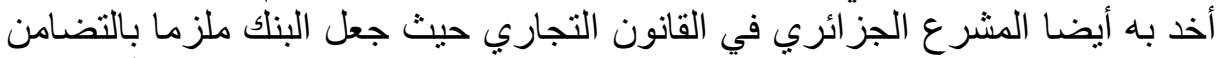

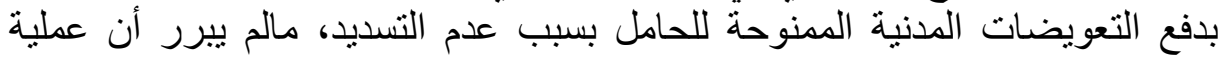

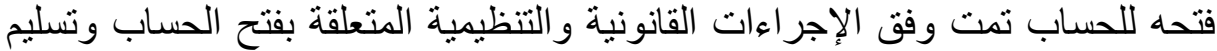

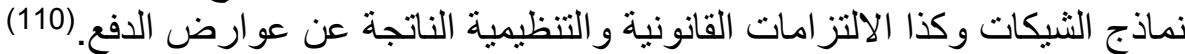

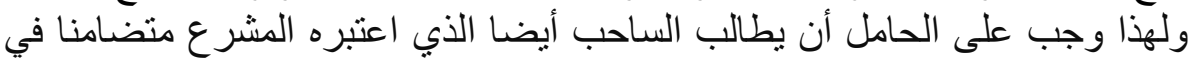

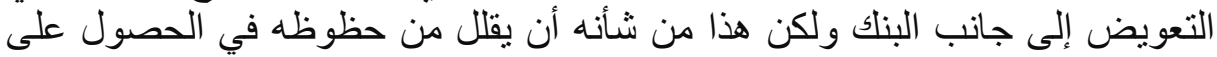

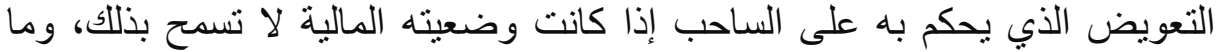

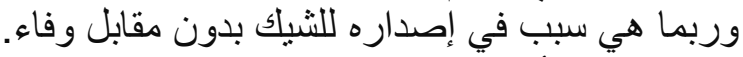

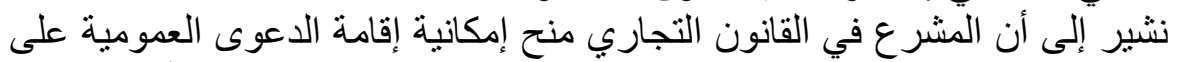

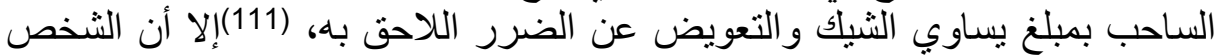
المؤهل للمطالبة بقيمة الثيك هو المستفيد (112)أي من استلم السند من النئ الساحب مبانشرة

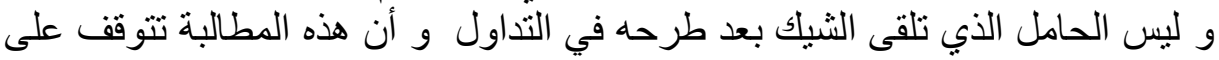

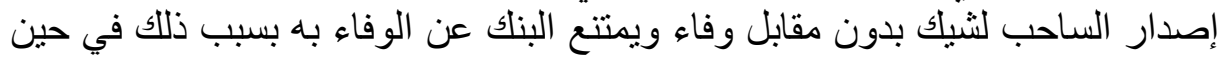

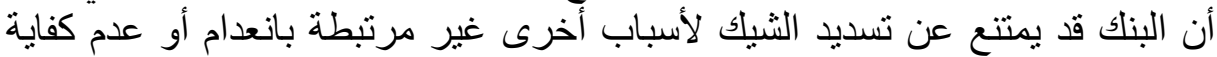

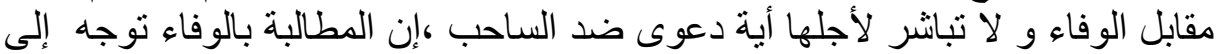

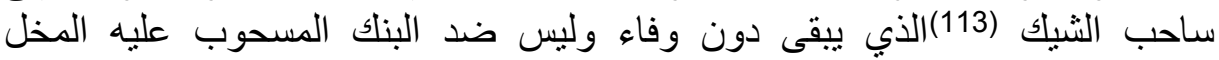

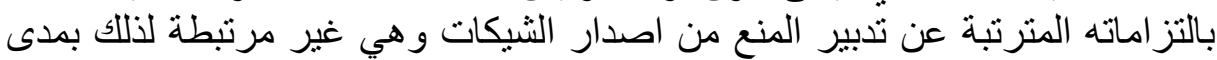

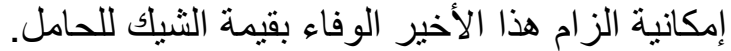

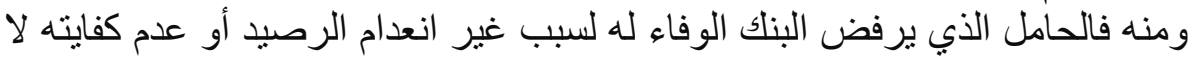

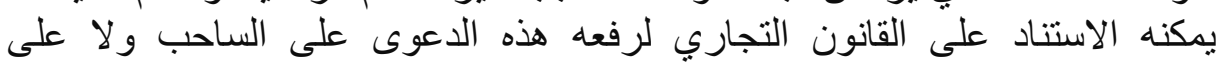
المسحوب عليه. 
لأنتائج ومناقشتها: -III

يتبين من خلال العرض السابق أن رفض البنك لوفاء الثيك يكون في عدة التئن حالات،

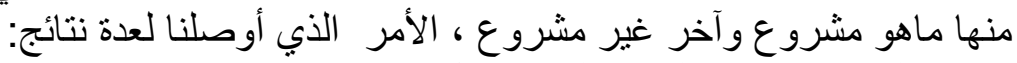

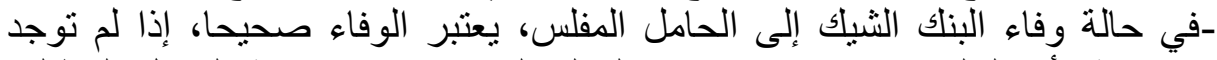

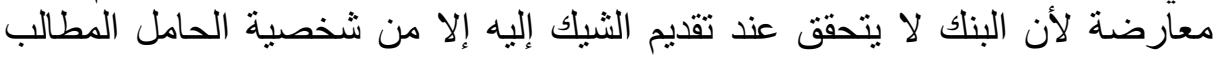

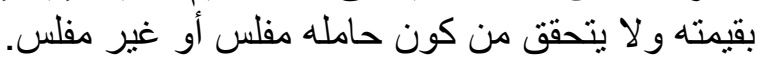

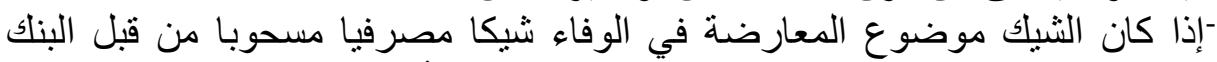

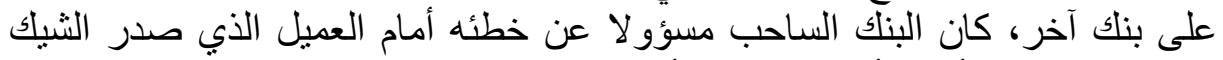

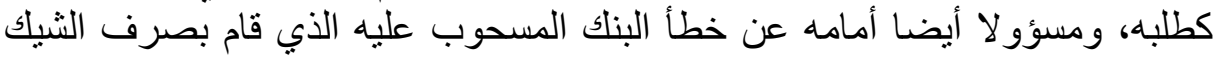
رغم إخطاره بوقف الدفع.

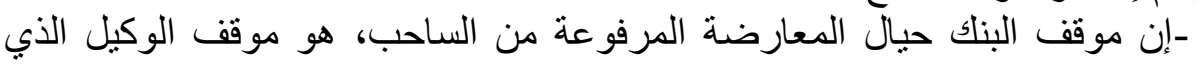

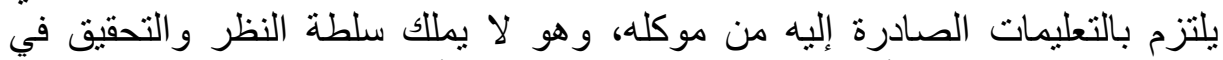

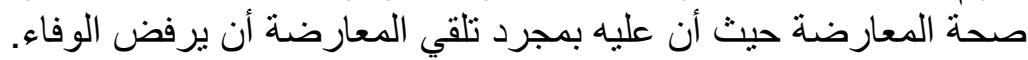

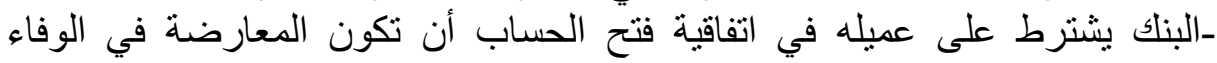

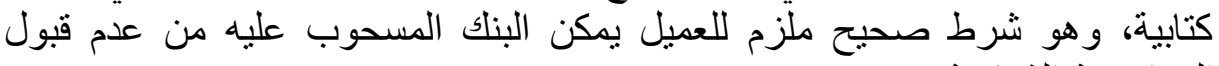
المعارضة الثفاهية. -ضمن حالات التي يحق للبنك رفض الوفارة الوفاء لحامل الثيك، هو تجميد الرصبي لصالح

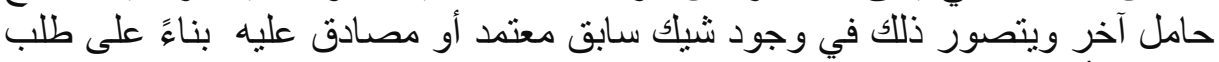

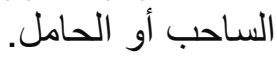
- بمجرد تلقي البنك المسحوب عليه شيك ليس له رصيد كاف أو أو منعدم، يقوم بإعداد

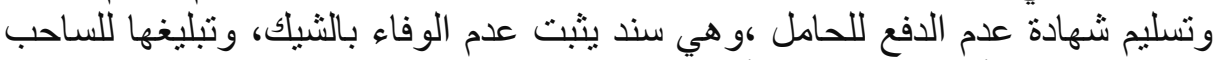

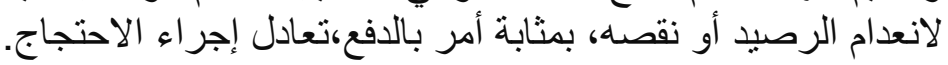

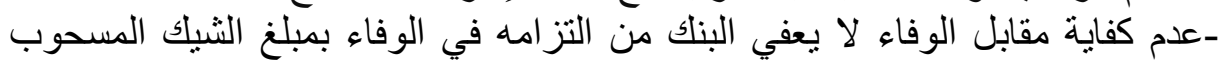

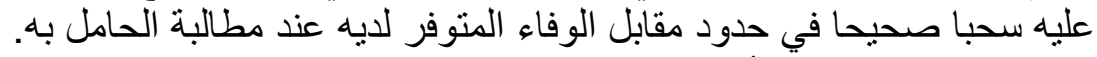

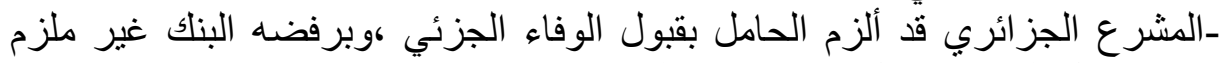

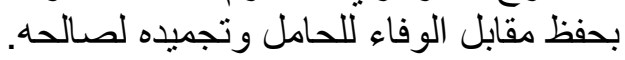

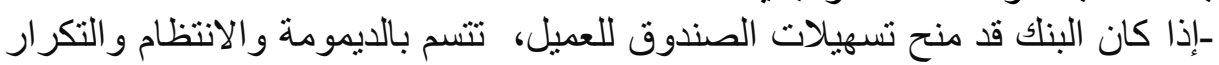

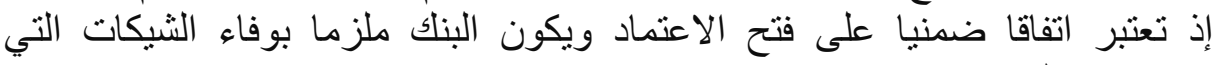
يسحبها عمبله.

- إذا كان للساحب مبالغ متمثلة في ودائع لأجل، أو شهادات استثمار أو غير ها ، جأ جاز

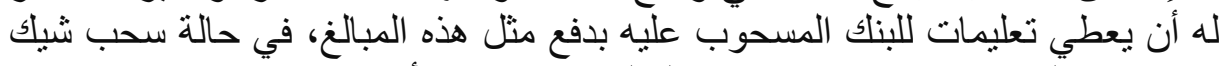

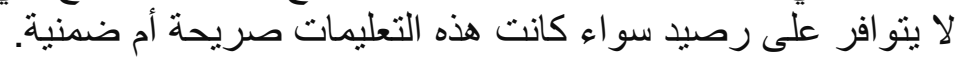

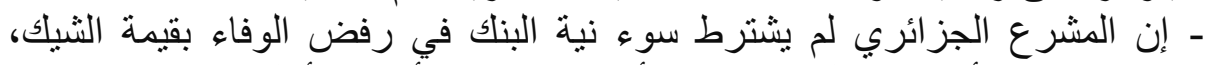

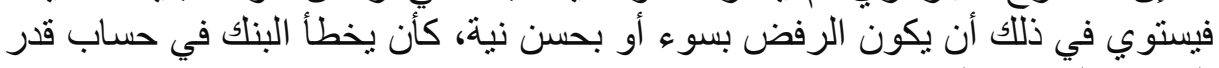
الرصبد الموجود لديه.

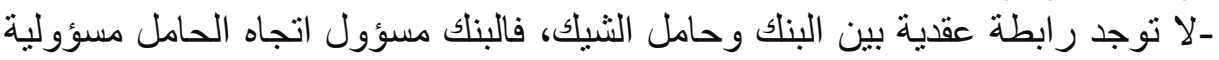

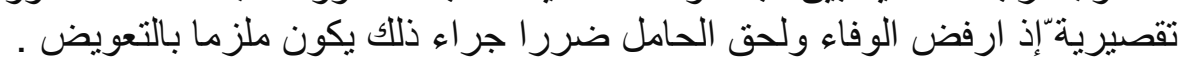




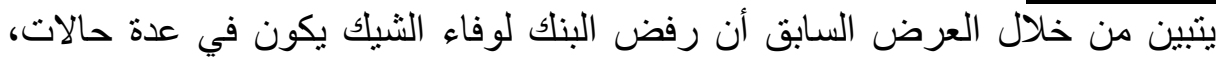

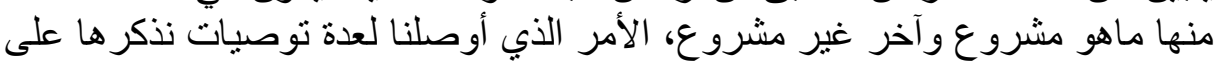

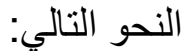

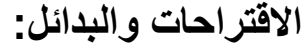

ـ على المشرع الجزائري الذي يعتبر الساحب قد أصدر شيك دون رصيد ليس ليس له مقابل

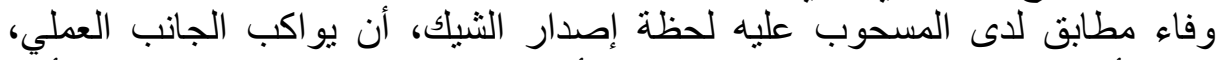

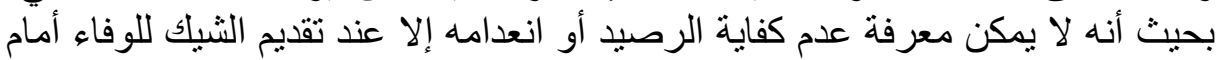

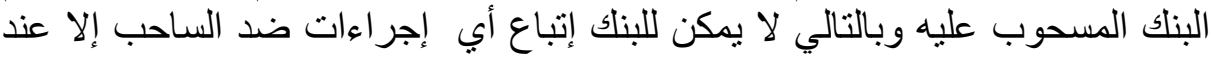

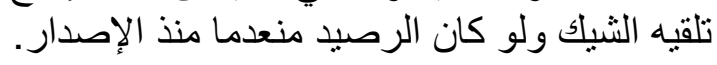

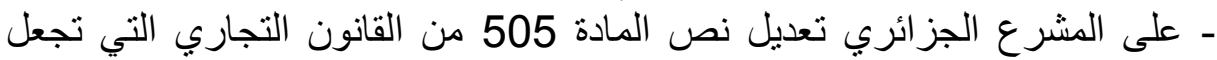

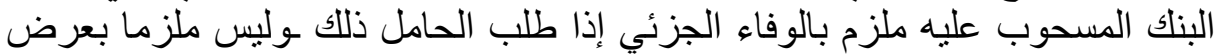
هذا الوفاء هذا ما يؤدي لحرمان الملتزمين في الثيك ماليك من البراءة الجزئ الجئية.

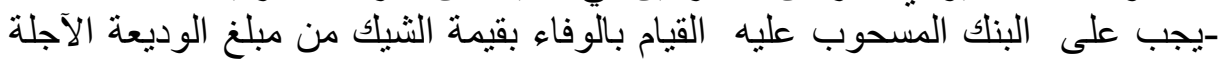

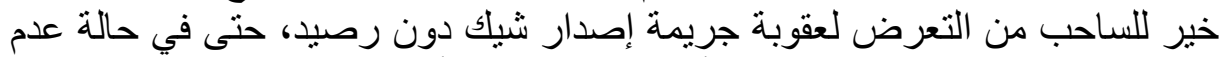

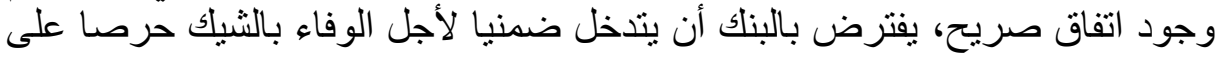
سمعة العميل ومصلحته.

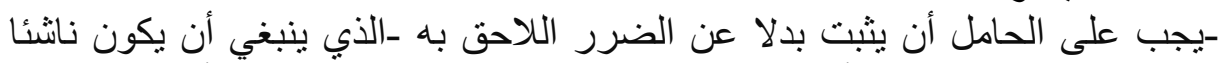

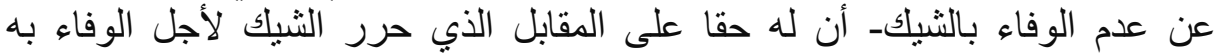

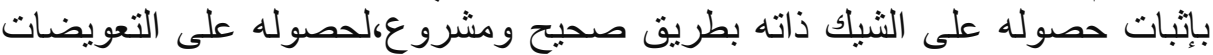

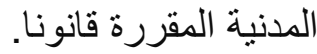

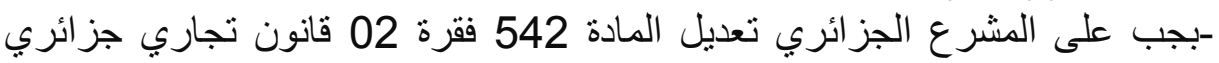

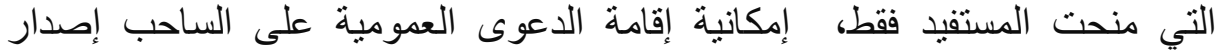

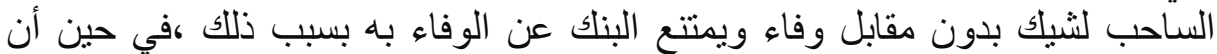

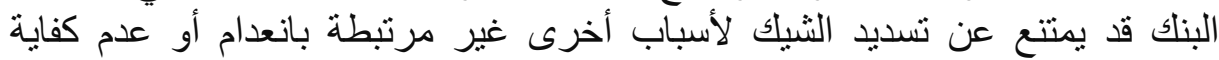

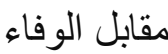
إضافة إلى أن المطالبة بالوفاء توجه إلى ساحب الثيك الذي يبقى دون وفاء وليس

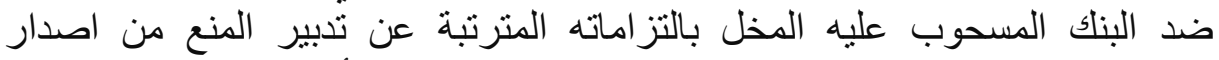

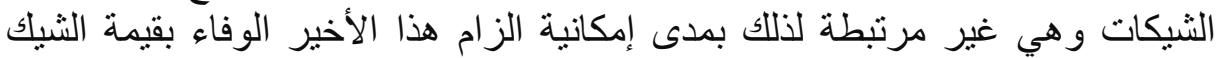

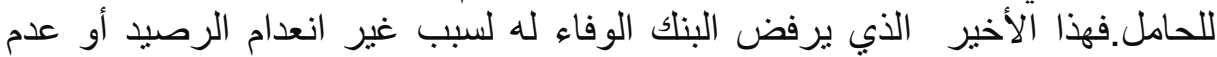

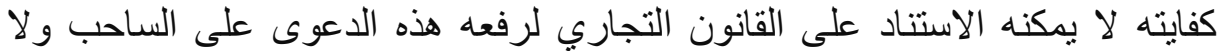
على المسحوب عليه. وفي الأخير كل هذا لأجل حماية الثيك الورقي كأدة تحتل المرتبة الأولى في الوفاء، إلهاء

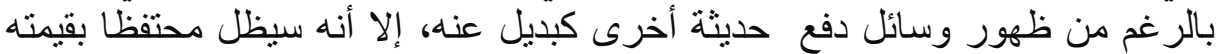

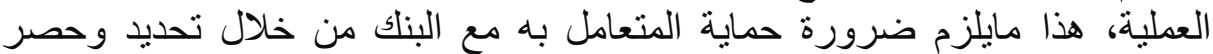

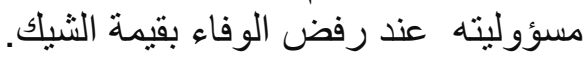

(1)-أنظر: فائق محمد الثماع، الحساب المصرفي دراسة مقارنة، دار الثقافة للنشر و التوزيع، عمان

(2)-أنظر: مؤيد حسن، طو البة، حسابات الصكوك ومسؤولية المصارف "الثنيكات" دار و ائل للنشر ،

(3)- العتابي بشير، الامتناع عن الوفاء بالثيك وآثاره، طبقا لأحدث التعديلات القانون التجاري، دار

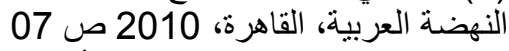

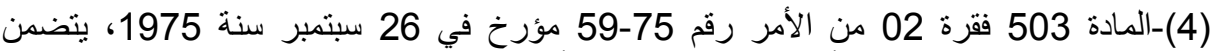
القانون التجاري: معدل ومنمم. أنظر الموقع الرسمي لأمانة العامة للحكومة: 
"و لا تقبل معارضة الساحب على وفاء الثيك إلا في حالة ضياعه أو تفليس حامله"

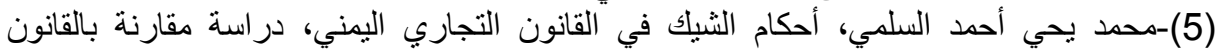

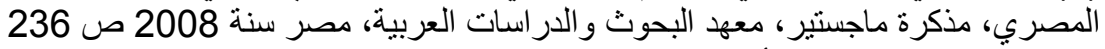

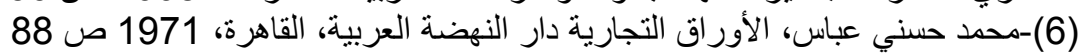

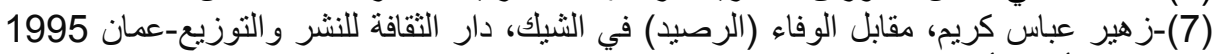

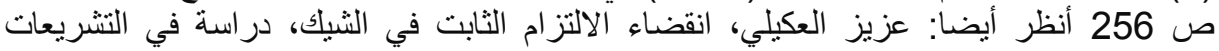

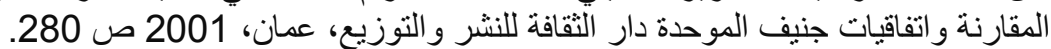

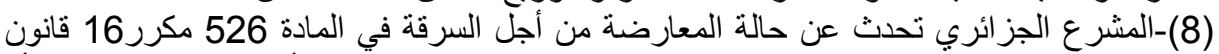

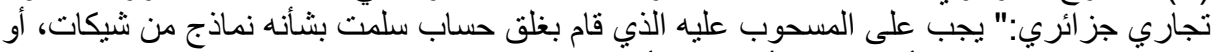

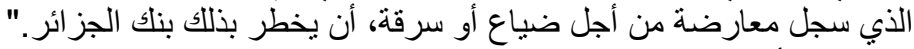

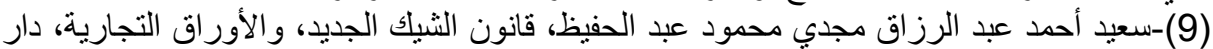

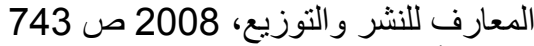

210 a 210 (10)

- La loi française $n^{\circ}$ 91-1382 du 30 décembre 1991 relative à la sécurité des chèques et des cartes de paiement, a ajouté d'autres cas à l'opposition à l'article 30 , paragraphe 01 , qui est le viol, le vol de chèques, la contrainte et l'utilisation frauduleuse du chèque. www.legifrance.fr

(11)-فياض مفلي، شرح القانون التجاري الأوراق التجارية الطبعة الثانية دار وائل للنشر والتوزيع عمان 2012 ص 2011 صنافي 427

(12)-يقصد بإفلاس الحامل هو صدور حكم بشهر إفلاسه ولا تكفي حالة التوقف عن الدفع، غير أن

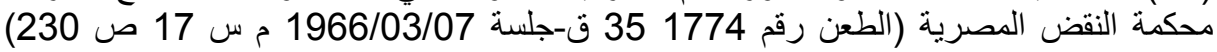
ذهبث إلى جواز المعارضة في هذه الحالة بمجرد وجود دعوى مرفوعة ضد الحامل بطلب شهر

(13)-عبد الفتاح سليمان، استخدام الثيك ومشكلاته العملية وحلولها في المملكة العربية السعودية، دار

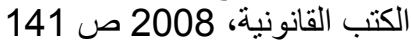

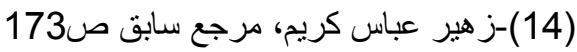

(15)-VASSEUR Michel, MARIN Xavier, Le chèque, Tom 2, Sirey, Paris, 1962, P. 12.

(16)-شفيق محسن القانون التجاري المصري الأوراق التجارية منشأة المعارف، الإسكندرية 1954

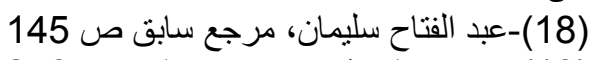

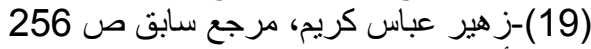

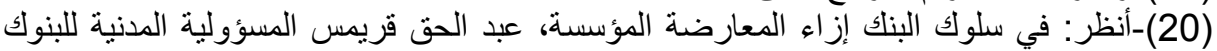

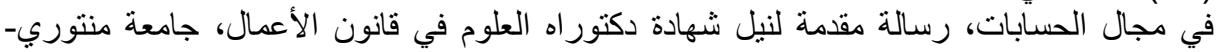

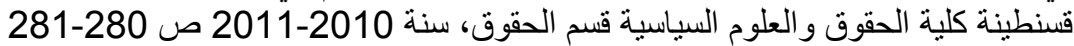
(21)-عبد الفتاح سليمان مرجع سابق صوم 128 (21)

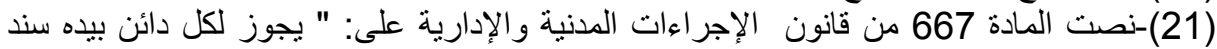

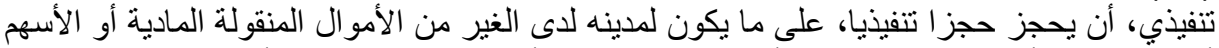

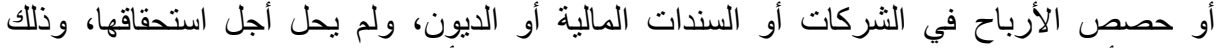

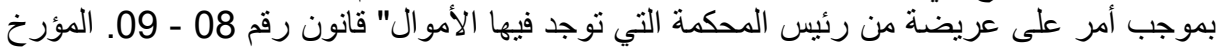

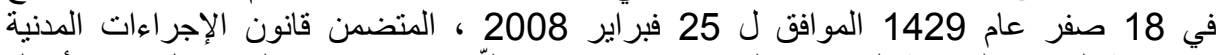

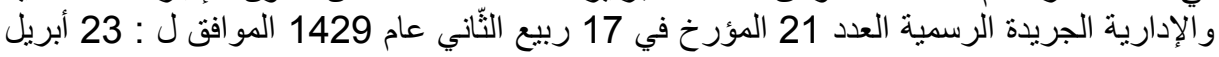
سنة 2008 م

(22)-نصست المادة 677 قانون إجراءات مدنية و إدارية على: " يجب على المئ المحجور لديه أن بقلم

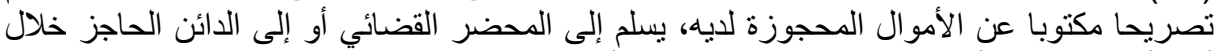

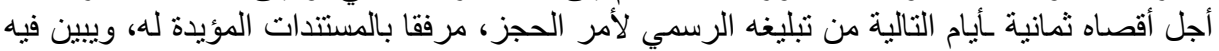

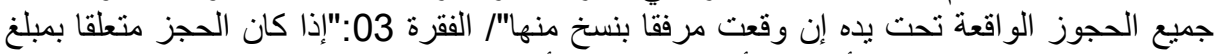

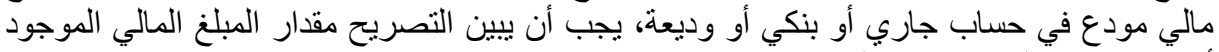

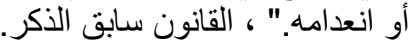


(23)-بصطلح عليه بالسر المصرفي ويعني عدم الكثف عن أية معلومة تتعلق بالعميل إلى طرف البـاف

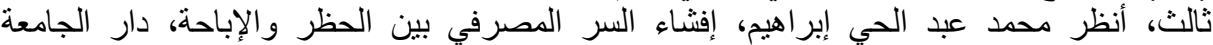

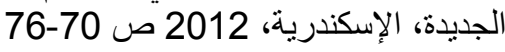

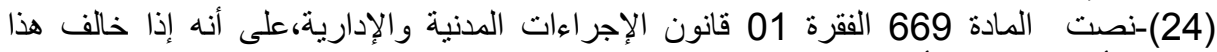

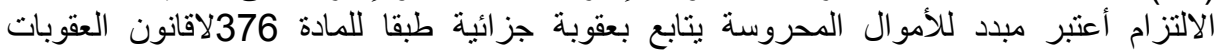

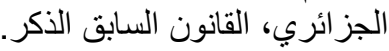

(25)-محسن شفيق الوسيط في القانون التجاري المصري الجزء 01 التئ مكتبة النهضة العربية

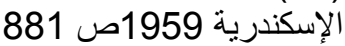

(26)-علي جمال الدين عوض، الثيك فيك في قانون التجارة، دار النهضة العربية القاهرة 1998ص85

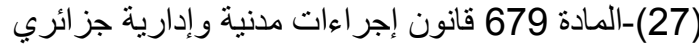

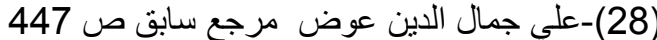

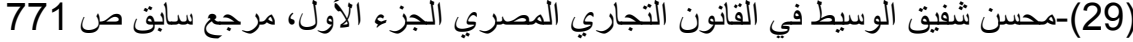

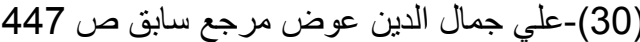

(31)-محمد محمود المصري أحكام الثيك مدنيا وجنائيا، المكتب العربي الحديث، الإسكندرية 2000

170-169 ص

(32)-George Ripert et René Robot, Traité le droit commercial, 11éme édition, L GDJ, Paris,1988, p 97.

$$
\text { (33)-المادة } 483 \text { قانون تجاري جزائري }
$$

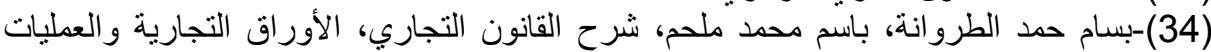

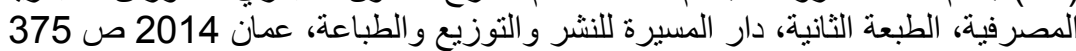

(35)-المادة 03 من الملحق الأول من الاتفاقية الأولى، مؤثمر جنيف الذئية الذي انعقد في فيفري 1931

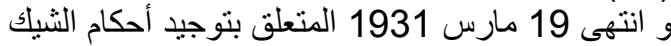

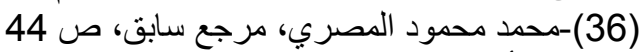

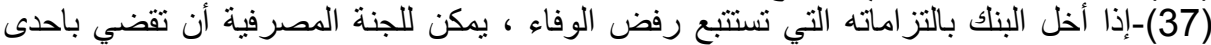

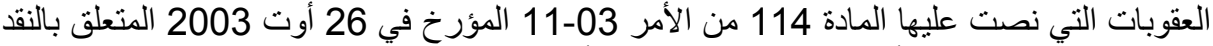

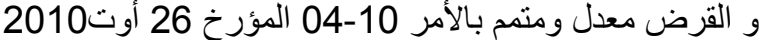

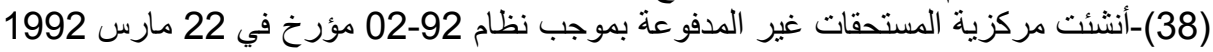

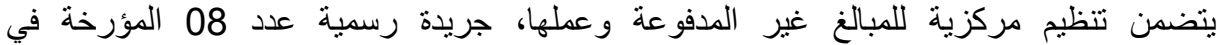

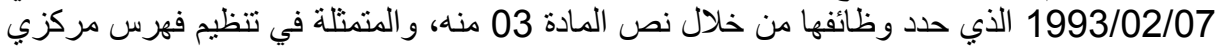

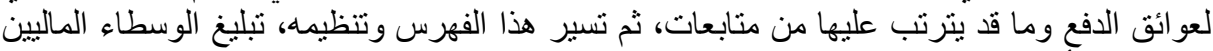

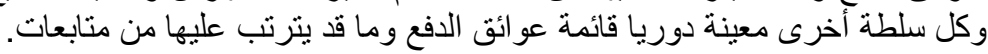

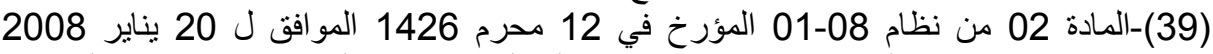
جريدة رسمية عدد 33 المؤرخ 22 يونيو 2008 المتعلق بترنيبات الوقاية من إصدار شيك بدون (40) - (4) ومكافحتها.

(40)-المادة 526مكرر قانون تجاري جز ائري

(41)-Article 03, instructions de la banque d'Algérie n01-11 du 09 Mars 2011 fixant les modalités d'application du règlement $n^{\circ} 08-01$ du 20 janvier 2008 relatif au dispositif de prévention et de lutte contre l'émission de chèques sans provision.

$$
\text { (42)-المادة } 526 \text { مكرر } 02 \text { قانون تجاري جزائري. }
$$

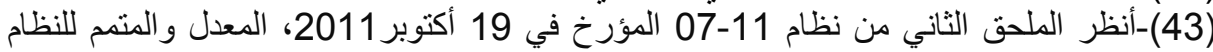

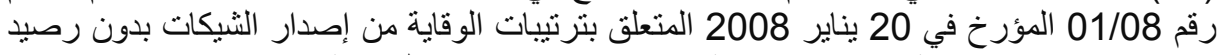

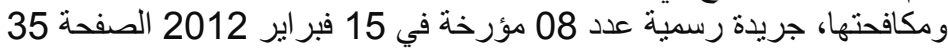
(44)-Article14 instructions de la banque d'Algérie n01-11 du 09 Mars 2011 fixant les modalités d'application du règlement $n^{\circ} 08-01$ du 20 janvier 2008 relatif au dispositif de prévention et de lutte contre l'émission de chèques sans provision. Voir : www.bank-of-algeria.dz (45)-المادة 526 مكرر03 قانون تجاري جزائري، والمادة 09 مكرر من النظام رقم 08-01

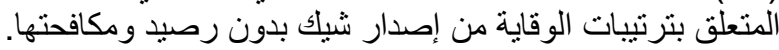

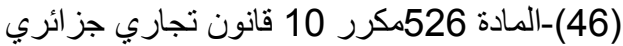

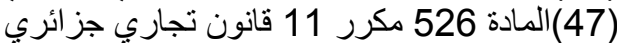
(48)- المادة 02 من نظام 11-07 المنعلق بترتيبات الوقاية من إصدار الثيكات بدون رصيد 
(49)- المادة 536 فقرة قانون تجاري جز ائري.

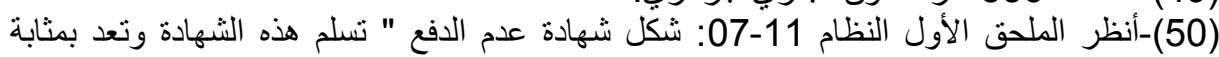

احتجاج بموجب التظظيم و التثريع المعمول بهما حاليا"

(51)-يتضح هذا من نص المادة 374 قانون العقوبات الجزائري

(52)-Vasseur Michel et Marin Xavier op.cit. p 68

$$
\text { (54)-المادة } 472 \text { 537الفقرة الأخيرة قانون تجاري جائري جزي مائري }
$$

(55)-أحمد محمد محرز السندات التجارية، الكمبيالة السند الإدني، الثيك، النسر الذهبي للطباعة

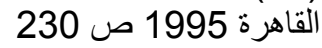

(56)-Vasseur Michel et Martin Xavier, op.cit. P47

(57)- Vasseur Michel et Martin Xavier, op.cit. p 51

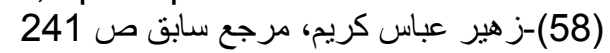

(59)-جمال عبد الناصر المسالمة العيوب الثكلية والعيوب الثنكلية والعيوب الموضوعية في الثيك

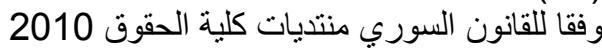

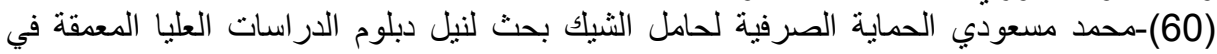

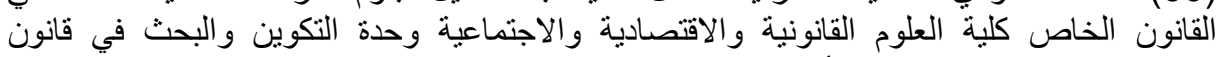
المقاو لات جامعة محمد الخامس أكدال-الرباط المغرب الماند

(61)-Michel jean tin et Paul le connu instruments de paiement et crédit entreprises en difficulté 5 édition Dalloz 1999 p 57

(62)-المادة07 من قانون رقم 01-01 مؤرخ في 06 فبر اير سنة 2005 ينعلق بالوقاية من تبيضض

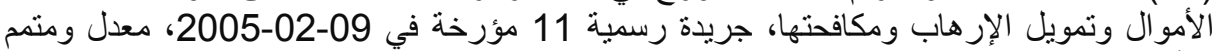

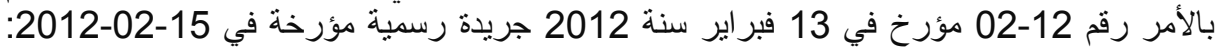

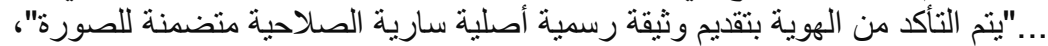

(63)-Michal Cabrillac. Le chèque et le virement, 4 édition librairies technique paris.1' 1969 p 35

(64)- المادة 505 من القانون التجاري الجزائري: (يحق للمسحوب عليه أن يطلب من الحامل عند

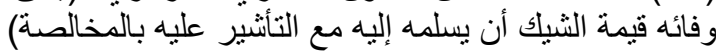

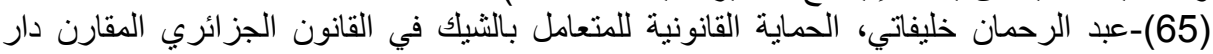

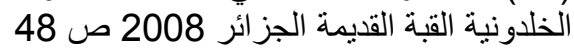

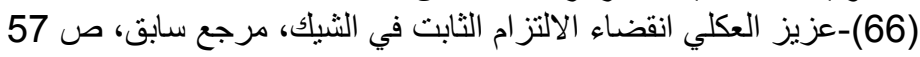
(67)-Juris classeur, banque et crédit, éditions technique- Dalloz, jurisclasseurs 1993 fascicule 320 p07

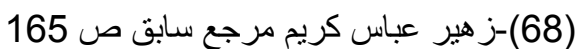
(69)-مصطفى كمال طه، أصول القانون القون التجاري المصري الأوراق التجارية والإفلاس الطبعة

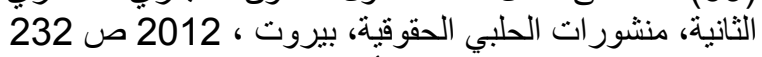

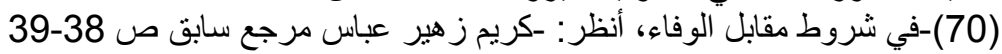

- العكيلي عزيز مرجع سابق ص ص 58 - 51 -

-فوزي محمد سامي فائق الثماع، الأوراق التجارية دار الثقافة للنشر والتوزيع عمان 1988ص

-سميحة القيلوبي الأوراق التجارية، الكمبيالة، السند لأمر، الثيك السياحي، الثيك المسطر، الثيك

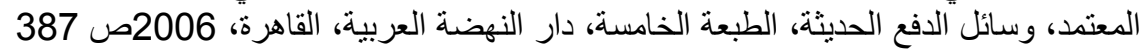

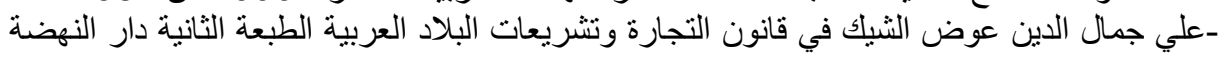

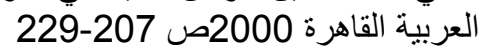

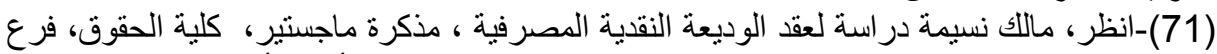

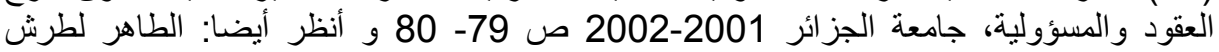

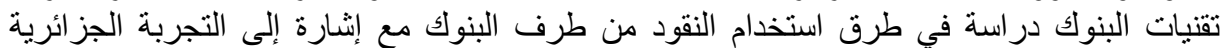

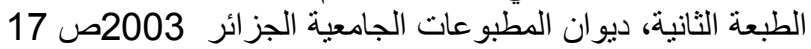

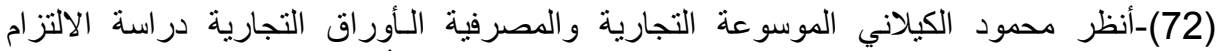
الصرفي - سند الكمبيالة الثيك درسة مقارنة المجلد الثالث الطبعة الأولى دار الثقافة للنشر و التوزيع، الترالئ (73)-Vasseur Michel et marin Xavier, op.cit. p 78 عمان 2009 ص 66 


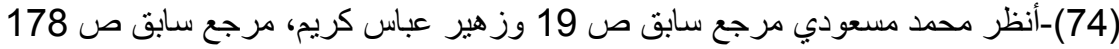

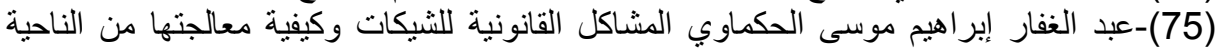

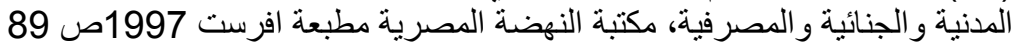

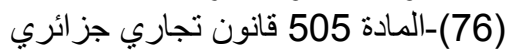

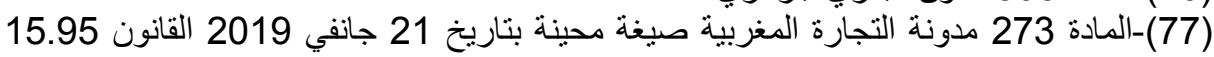

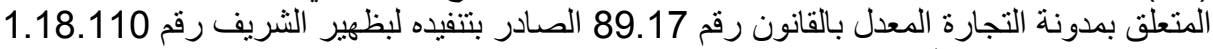

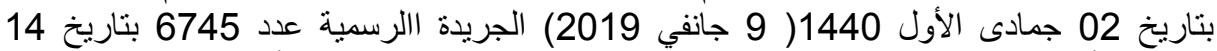

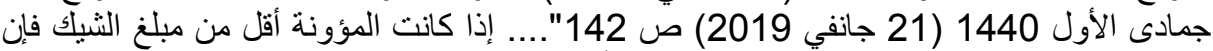

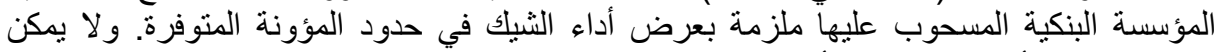

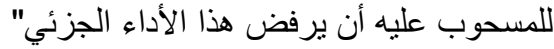

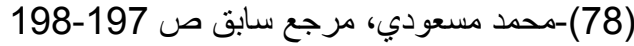

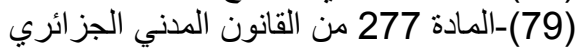

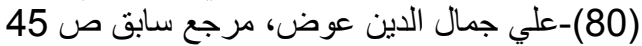

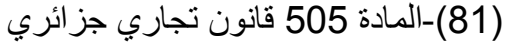

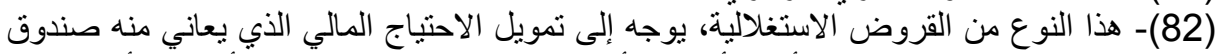

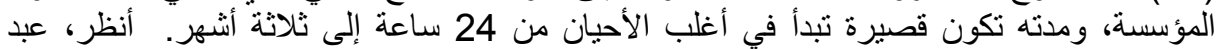

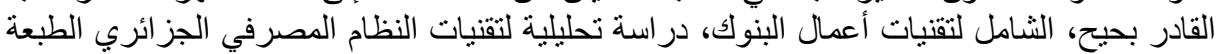

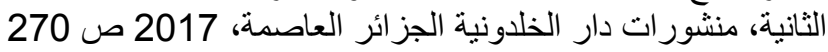

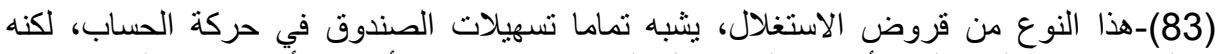

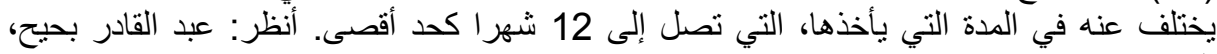

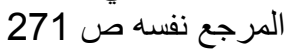

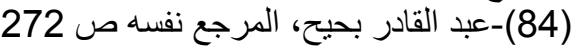
(85)- VEZIAN Jack, La responsabilité du banquier en droit privé français, 3e édition, Litec, Paris, 1983, P.99

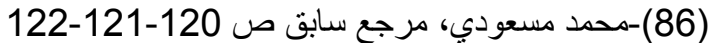

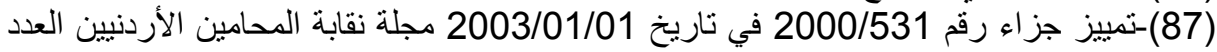

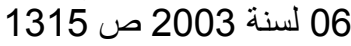

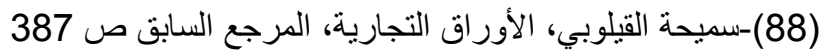

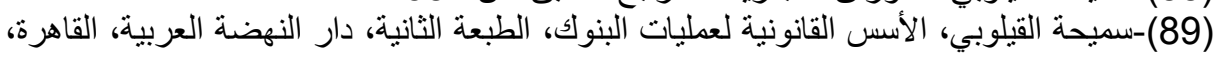

465 صن 2003

(90)-المادة 537 فقرة 07 من القانون التجاري.

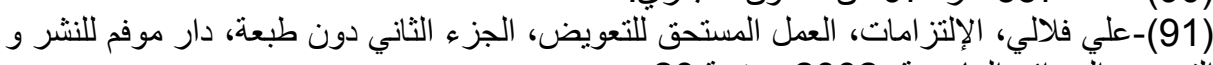

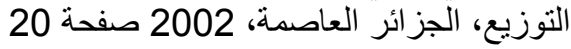

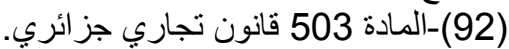

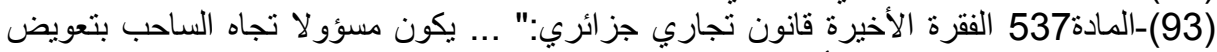

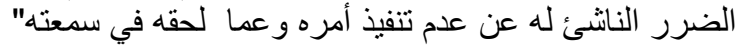

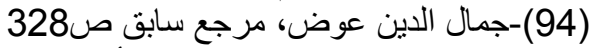

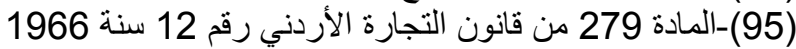

(96)-Michel Cabrillac le chèque et le virement 4 e édition Librairies techniques Paris1967 p35

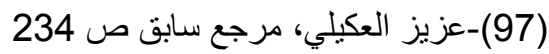

(98)-GAVALDA Christian, STOUFELET Jean, Droit de la banque, PUf, Paris, 1974, P. 333.

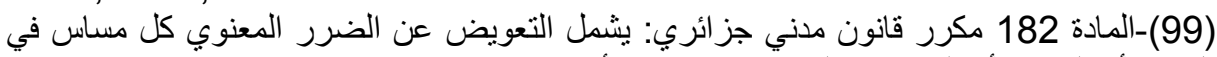

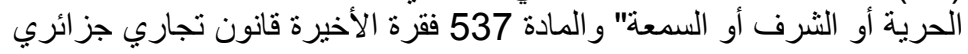

(100)-Tribunal com seine 20/12/1951 gaz pal p 160

(101)-علي جمال الدين عوض، عمليات البنوك من من الوجهة القانونية الطبعة الثالثة دار النهضة العربية، القاهرة، 2000 ص ص 2010

(102)- Cass.com03 janvier 1970.not jack Vézina ; la responsabilité du banquier en droit privé français librairies technique 1974 p 121

(103)-Michel. Cabrillac, le chèque et le virement, op.cit. p 22

(104)-المادة 124 القانون المدني الجز ائري 'كل من فعل أيا كان برتكبه الثخص بخطئه ويسبب ضررا للغير يلزم من كان سببا في حدوثه بالتعويض' الئري 
(105)-عزيز العكيلي ، مرجع سابق ص . C 360

(106)-Michel, Cabrillac, le chèque et le virement, op. Cit. P 36

(107)-المادة 124 من القانون المدني الجزائري

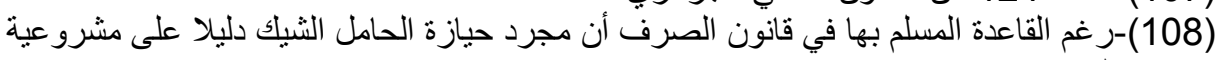

حقه في الوفاء.

(109)- Loi $n^{\circ} 10$ du 3 janvier 1972 relative à la prévention et à la répression des infractions en matière de chèques

(110)-المادة 526مكرر 15 قانون تجاري جز ائري

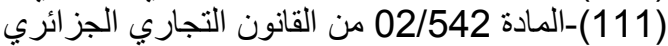

(112)-المادة 542 فقرة 02 قانون تجاري جزائري لئري " ... فإن المستفيد من الثيك الذي يدعي بالحق

الدئي يجوز له المطالبة....

(113)-المادة 542 فقرة 02 قانون تجاري جزائري " ... إذا أقيمت الدعوى الجزائية على

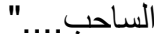

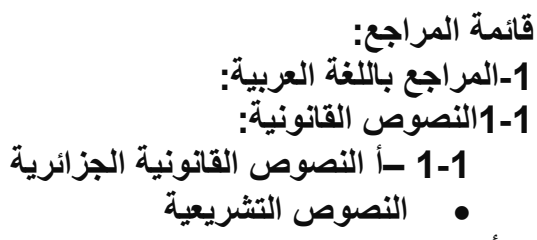

1أس-أمر رقم 66-156 مؤرخ في 8 يونيو 8 يونيو 19966 يتضمن قانون العقوبات، معدل و متمم، لاسيما

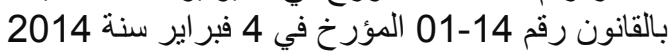

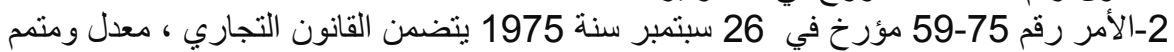

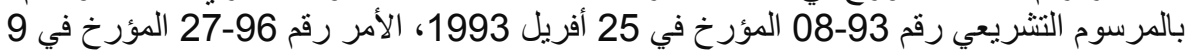

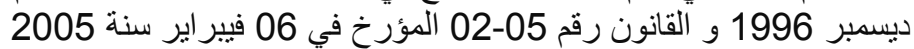

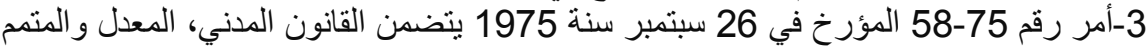

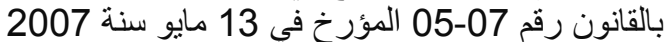

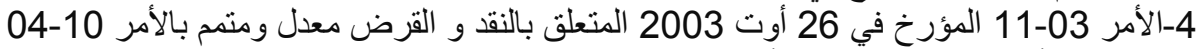

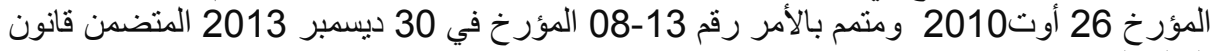

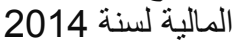

5-قانون رقم 05-01 مؤرخ في 06 فبر اير سنة 2005 بتعلق بالوقاية من تبييض الأمو ال وتمويل

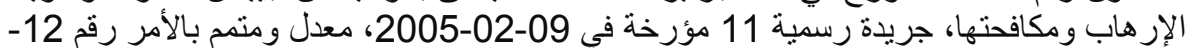

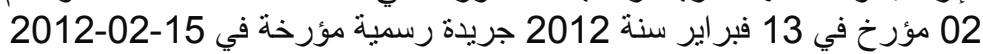

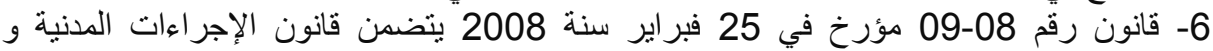
الإدارية • ب النصوص التنظيمية

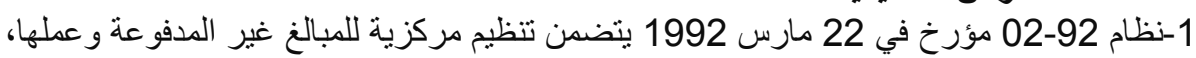

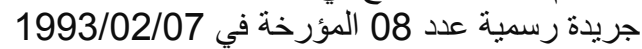
2-نظام 01-08 المؤرخ في 12 محرم 1426 الموافق لون 20 يناير 2008 المتعلق بترتيبات الوقاية من إصدار شيك بدون رصيد ومكافحتها.

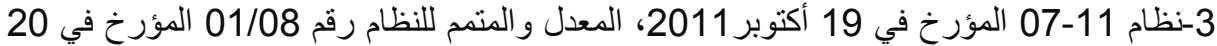

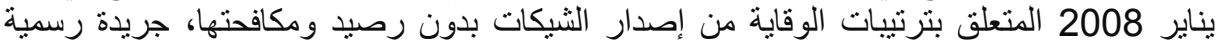
عدد 08 مؤرخة في 15 فبر اير 2012 الصفحة 35

1-1-1 النصوص القانونية العربية 1-1-1-1-بنون التجارة الأردني رقم 12 سنة 1966

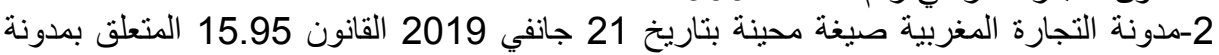

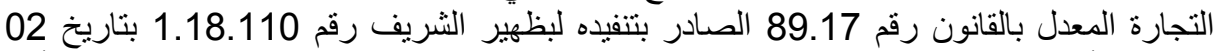
جمادى الأول 1440( 9 جانفي 2019) الجريدة الرسمية عدد 6745 بتاريخ 14 جمادى الأول

(21 جانفي 2019) 
1-أحمد محمد محرز السندات التجارية، الكمبيالة السند الإدني، الثيك، النسر الذهبي للطباعة القاهرة

2-الطاهر لطرش تقتيات البنوك دراسة في طرق استخدام النقود من طرف البنوك مع إثـارة إلى البى

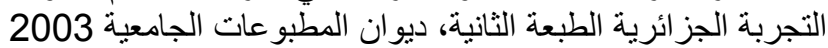

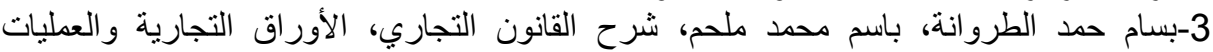

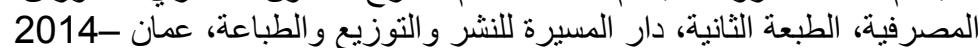

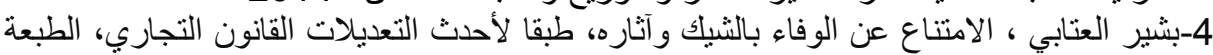

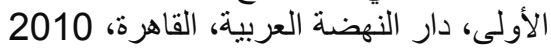

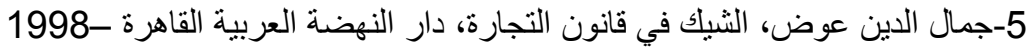
6-حسن شفيق الوسيط في القانون التجاري المصري الجئ الجزء 01 مكتبة النهضة العربية الإسكندرية

7-زهير عباس كريم، مقابل الوفاء (الرصيد) في الثيك، دار الثقافة للنشر و التوزيع-عمان 1959 8-سميحة القيلوبي، الأسس القانونية لعمليات البنوك، الطبعة الثنانية، دار النهضة النية العربية، القاهرة،

9-سميحة القيلوبي الأوراق التجارية، الكمبيالة، السند لأمر، الثيك السياحي، الثيك السبطر، الثيك الثيك

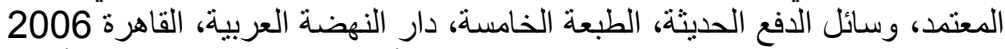
10-شفيق محسن القانون التجاري المصري الأوراق التجارية الطبعة الأولى منشأة المعارف، الإسكندرية 1954 الرئ 19 11-عبد الرحمان خليفاتي، الحماية القانونية للمتعامل بالثيك في القانون الجزائري المقارن دار الخلدونية القبة القديمة 2008

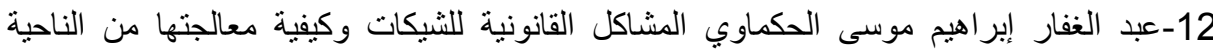

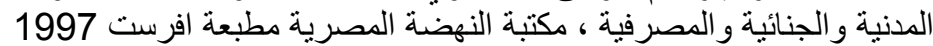
13-عبد الفتاح سليمان، استخدام الثبك ومشكلاته العملية العلية وحلولها في المملكة العربية السعودية، دار الكتب القانونية 2008

14-عبد القادر بحيح، الثامل لتقنيات أعمال البنوك، دراسة تحليلية لتقنيات النظام المصرفي

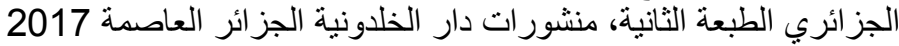
15-علي جمال الدين عوض الثيك في قانون التجارة وتشريعات البلاد العربة العربية الطبعة الثانية دار النهضة العربية القاهرة 2000 16- علي جمال الدين عوض، علمبة عليات البنوك من الوجهة القانونية الطبعة الثالثة دار النهضة

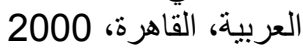
17-عزيز العكيلي، انقضاء الالتزام الثابت في الثيك، دراسة في التشريعات المقارنة و اتفاقيات جنيف

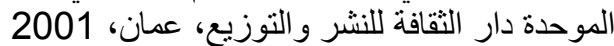
18- علي فلالي، الإلتزامات، العمل المستحق للتعويض، الجزء التهاء الثاني دون طبعة، دار موفم للنشر و

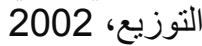
19-فائق محمد الثماع، الحساب المصرفي دراسة مقارنة، دار الثقافة للنشر و التوزيع، عمان- 2009

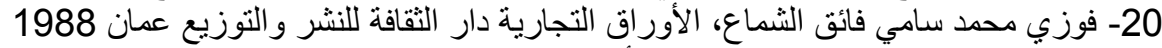
21-فياض مفلي، شرح القانون التجاري الأوراق التجارية الطبعة الثانية دار وائل للنشر والتوزيع عمان- 2012 2012 22-مؤيد حسن، طو البة، حسابات الصكوك ومسؤولية الدصارف "الثيكات" دار و ائل للنشر، عمان2004

23-محمود الكيلاني الموسوعة التجارية والمصرفية الـأوراق التجارية دراسة الالتزام الصرفي ـ

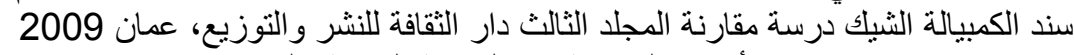

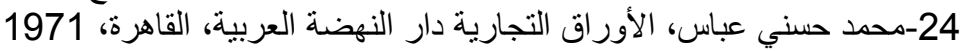

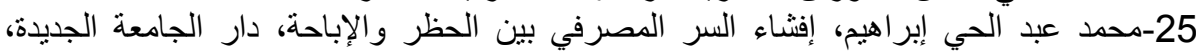

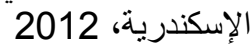

26-محمد محمود المصري أحكام الثيك مدنيا وجنائيا، المكتب العربي الحديث، الإسكندرية 2012

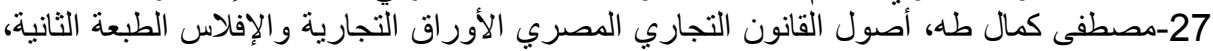
منشور ات الحلبي الحقوقية، بيروت، 2012

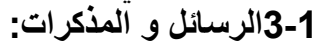
1-عبد الحق قريمس المسؤولية الددنية للبنوك في مجال الحسابات، رسالة مقدمة لنيل شهادة دكتور راه العلوم في قانون الأعمال، جامعة منتوري-قسنطينة كلية الحقوق والعلوم السيانية العياسية قسم الحقوق، 2011-2010 2-ماللك نسيمة دراسة لعقد الوديعة النقدية المصرفية ، مذكرة ماجستير، كلية الحقوق ، فرع العقود و 
المسؤولية، جامعة الجز ائر 2001-2002 الحمبية

3-محمد مسعودي الحماية الصرفية لحامل الثيك الثيك بحث لنيل دبلوم الدراسات العليا المعمقة في القانون

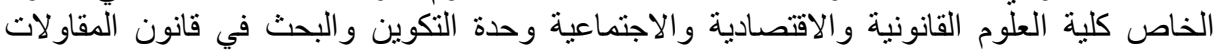

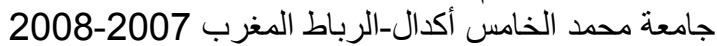

4-محمد يحي أحمد السلمي، أحكام الثيك في التيكية القانون التجاري اليمني، دراسة مقارنة بالقانون المصري، مذكرة ماجستير، معهد البحوث و الدر أسات العربية، مصر التجري 2008

2-1 Textes juridiques

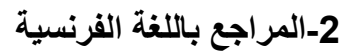

1-Loi $\mathrm{n}^{\circ} 10$ du 3 janvier 1972 relative à la prévention et à la répression des infractions en matière de chèques.

2- Loi n ${ }^{\circ}$ 91-1382 du 30 décembre 1991 relative à la sécurité des chèques et des cartes de paiement.

\section{2-2Les ouvrages}

1-Juris classeur, banque et crédit, éditions technique- Dalloz, juris-Classeurs 1993 fascicule 320

2-Gavalda Christian et Stofflet jean Droit de la banque presse universitaire de France, paris 1974

3-George Ripert et René Robot, Traité le droit commercial, 11éme édition, L GDJ, Paris, 1988 ,

4-Michal Cabrillac. Le chèque et le virement, 4 édition librairies

Technique paris.1' 1969

5-Michel Cabrillac le chèque et le virement 4 e édition 1967

6-Michel jean tin et Paul le connu instruments de paiement et crédit entreprises en difficulté 5 édition Dalloz 1999

7-Vasseur Michel et Marin Xavier ; le chèque, Tom 02 Sirey Paris 1969

8- Vézina Jack, La responsabilité du banquier en droit privé français, 3e édition, Lite 1983 